\title{
Seasonal variation in body composition, metabolic activity, feeding, and growth of adult krill Euphausia superba in the Lazarev Sea
}

\author{
Bettina Meyer ${ }^{1, *}$, Lutz Auerswald ${ }^{2}$, Volker Siegel ${ }^{3}$, Susanne Spahić $^{1}$, Carsten Pape $^{1}$, \\ Bettina A. Fach ${ }^{1,6}$, Mathias Teschke ${ }^{1}$, Andreas L. Lopata ${ }^{4,7}$, Veronica Fuentes ${ }^{5,8}$ \\ ${ }^{1}$ Alfred Wegener Institute for Polar and Marine Research, Scientific Division Polar Biological Oceanography, \\ Handelshafen 12, 27570 Bremerhaven, Germany \\ ${ }^{2}$ Marine \& Coastal Management, Private Bag X2, Rogge Bay 8012, Cape Town, South Africa \\ ${ }^{3}$ Sea Fisheries Institute, Palmaille 9, 22767 Hamburg, Germany \\ ${ }^{4}$ Allergy and Asthma Group, Division of Immunology, University of Cape Town, 7925 Observatory, Cape Town, South Africa \\ ${ }^{5}$ Department of Biodiversity and Experimental Biology, University of Buenos Aires, Buenos Aires, Argentina \\ ${ }^{6}$ Present address: METU Institute of Marine Sciences, Middle East Technical University, PO Box 28, 33731 Erdermli-Mersin, Turkey \\ ${ }^{7}$ Present address: School of Applied Sciences, RMIT University, Melbourne, Victoria, Australia \\ ${ }^{8}$ Present address: Institut de Ciéncies del Mar (CSIC), Passeig Maritim de la Barcelona 37-49, Spain
}

\begin{abstract}
We investigated physiological parameters (elemental and biochemical composition, metabolic rates, feeding activity and growth) of adult Antarctic krill in the Lazarev Sea in late spring (December), mid autumn (April) and mid winter (July and August) to evaluate proposed hypotheses of overwintering mechanisms. Our major observations are: (1) respiration rates were reduced by 30 to $50 \%$ in autumn and winter, compared to values in late spring; (2) feeding activity was reduced by 80 to $86 \%$ in autumn and winter, compared to late spring, at similar food concentrations; (3) feeding was omnivorous during winter; (4) with each moult, krill grew by 0.5 to $3.8 \%$ in length; (5) body lipids and, to a small extent, body proteins were consumed during winter. Adult Euphausia superba thus adopt metabolic slowdown and omnivorous feeding activity at low rates to survive the winter season in the Lazarev Sea. By mid autumn, metabolic activity is reduced, most likely being influenced by the Antarctic light regime, which is accompanied by a reduction in feeding activity and growth. Although at a low level, the feeding activity during winter seems to provide an important energy input.
\end{abstract}

KEY WORDS: Antarctic krill · Seasonal condition · Overwintering

Resale or republication not permitted without written consent of the publisher

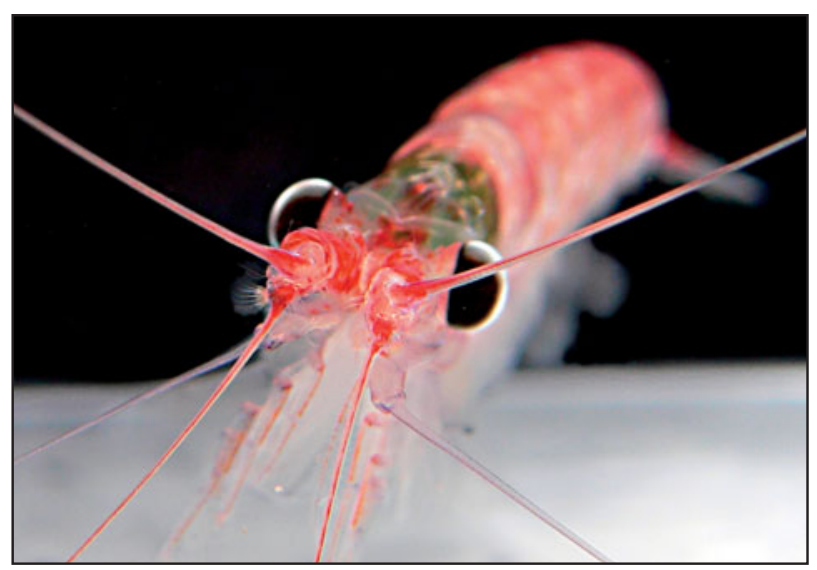

Antarctic krill Euphausia superba

Photo: Carsten Pape

\section{INTRODUCTION}

Antarctic krill (hereafter krill) is a key organism in the Southern Ocean and has been studied for over 80 yr. Despite this long history of research, owing to krill's vast distribution range and the inaccessibility of much of this, knowledge is still patchy and important scientific questions remain unanswered. In addition to 
the extent of sea ice coverage, overwintering success is regarded as a major factor that dictates physiological condition, survival, recruitment, and population size of krill in the Southern Ocean (Loeb et al. 1997, Atkinson et al. 2004). The biological mechanisms that facilitate the overwintering of krill are, however, still unclear.

Proposed overwintering mechanisms for adult krill fall into 2 categories: (1) non-feeding mechanisms, and (2) switching from algae in the water column to alternative food sources. Non-feeding strategies consist of the reduction in metabolic rates (Kawaguchi et al. 1986, Quetin \& Ross 1991, Torres et al. 1994a), shrinkage in size (Ikeda \& Dixon 1982, Quetin \& Ross 1991) and the utilisation of body lipids (Quetin \& Ross 1991, Hagen et al. 2001). Winter studies on krill have shown that alternative food sources might be zooplankton (Huntley et al. 1994) and seabed detritus (Kawaguchi et al. 1986). The reduction of metabolic and feeding rates to 60 and $20 \%$, respectively, of summer values has already been demonstrated in the Lazarev Sea in late autumn (Atkinson et al. 2002). The reasons for this metabolic slowdown are not completely understood, but recent research has indicated that Antarctic light regime, rather than food supply, might influence these seasonal physiological changes (Teschke et al. 2007).

All these adaptations to the winter season have been observed at different times and places, making it difficult to judge their relative significance. Even within one region, the Antarctic Peninsula, conflicting observations on krill overwintering have been made. For example, Quetin \& Ross (1991) reported that krill undergo lipid utilisation, shrinkage and a reduction in metabolic rates, whereas Huntley et al. (1994) found them feeding and excreting at summer rates. Such contradictory findings may point to methodological inconsistencies but could, on the other hand, be indications for an exceptional behavioural and physiological flexibility. The existence of 2 different overwintering mechanisms seems very unlikely, however, as both strategies (i.e. reduced metabolism and business as usual with high feeding activity and growth, as in summer) require specific adaptations on an organismic, cellular and molecular level that preclude each other. Much of our knowledge comes from a few regions, such as the intensively studied Antarctic Peninsula (Hofmann et al. 2004), and neither the local environment (e.g. along the Antarctic Peninsula) nor the response of krill to it should be extrapolated easily to a wider area. Thus, one prerequisite for a generalisation of krill overwintering is a better geographic coverage.

This was attempted as part of the Lazarev Sea Krill Study (LAKRIS), the German contribution to the Southern Ocean Global Ocean Ecosystem Dynamics (SOGLOBEC) program. The Lazarev Sea (Fig. 1) is the eastern part of a broad region of high krill abundance, which extends from the Antarctic Peninsula to the

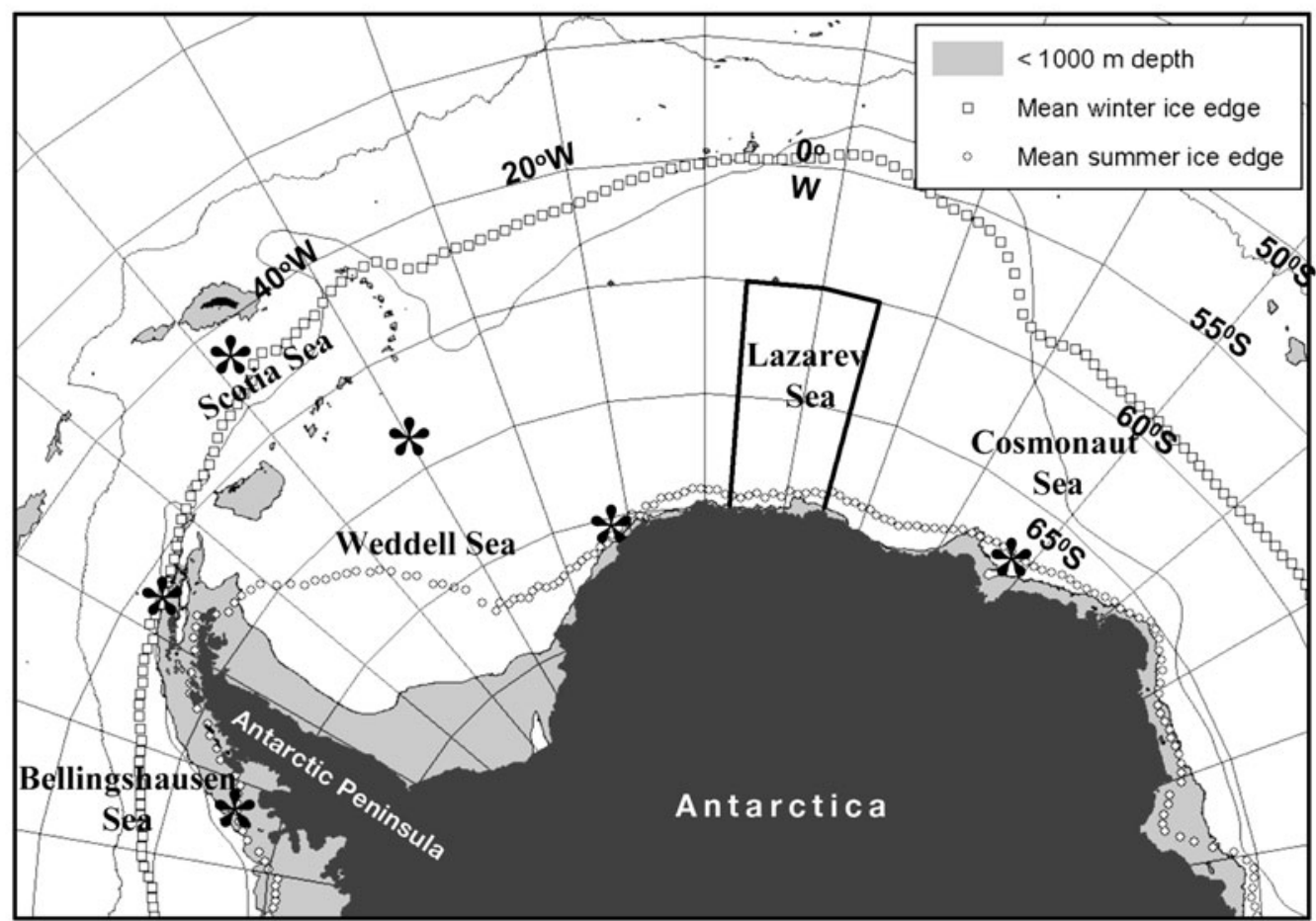

Fig. 1. Lazarev Sea study area in relation to other winter studies in the Southern Ocean (**) with mean summer and winter ice edges (based on NOAA ice data from 1979 to 2006). Irregular grey lines (from north to south): Antarctic Polar Front and Southern Boundary of the Antarctic Circumpolar Current 
Greenwich Meridian (e.g. Marr 1962, Atkinson et al. 2008). This area shows the widest latitudinal range of krill throughout their entire circumpolar distribution, stretching from $50^{\circ} \mathrm{S}$ to the Antarctic continent at $70^{\circ} \mathrm{S}$. The continental shelf is narrow and the majority of krill live in the oceanic region, where water depths exceed $4000 \mathrm{~m}$. Only a few historical data on krill from this area exist, focusing mainly on distribution and abundance (e.g. Makarov \& Sysoyeva 1985), and only a few studies provide data on their physiology (Atkinson et al. 2002, Schmidt et al. 2003, Stübing \& Hagen 2003).

The present study covered different seasons-i.e. late spring and the beginning of summer (December), mid autumn (April) and mid winter (July and August) - in the Lazarev Sea, and a wide range of analytical methods were applied. In addition to biotic and abiotic environmental conditions, we analysed (1) morphometrics, elemental composition, nutritional status and growth rates, (2) feeding activity and digestive gland (DG) indices, and (3) respiration and excretion rates and activity of metabolic enzymes. Concurrent with this suite of measurements on adults, we conducted a parallel study to determine overwintering mechanisms of larvae, reported in a separate paper (Meyer et al. 2009). The comprehensive data set we obtained from this investigation enabled us to draw a clearer picture of the behavioural and physiological responses that enable adult krill to survive the Antarctic winter.

\section{MATERIAL AND METHODS}

Surveys and environmental conditions. Three expeditions in austral late spring and beginning of summer (ANTXXIII-2, 19 November 2005 to 12 January 2006), mid autumn (ANTXXI-4, 27 March to 6 May 2004), and winter (ANTXXIII-6, 11 June to 27 August 2006) were carried out on board RV 'Polarstern' along 4 (late spring and beginning of summer, and mid autumn) and 3 (winter) parallel meridional transects which extended from $60^{\circ} \mathrm{S}$ to the Antarctic continent at $70^{\circ} \mathrm{S}$. The station grids for all 3 cruises are given in Fig. 2a-c. Highlighted stations mark the positions at which krill were caught for most of the presented analyses. During the late spring and beginning of summer survey, sampling of krill took place in the study area in December, hereafter referred to as late spring, whereas sampling took place in April during the autumn expedition and in July until mid-August during the winter expedition (Fig. 2a-c).
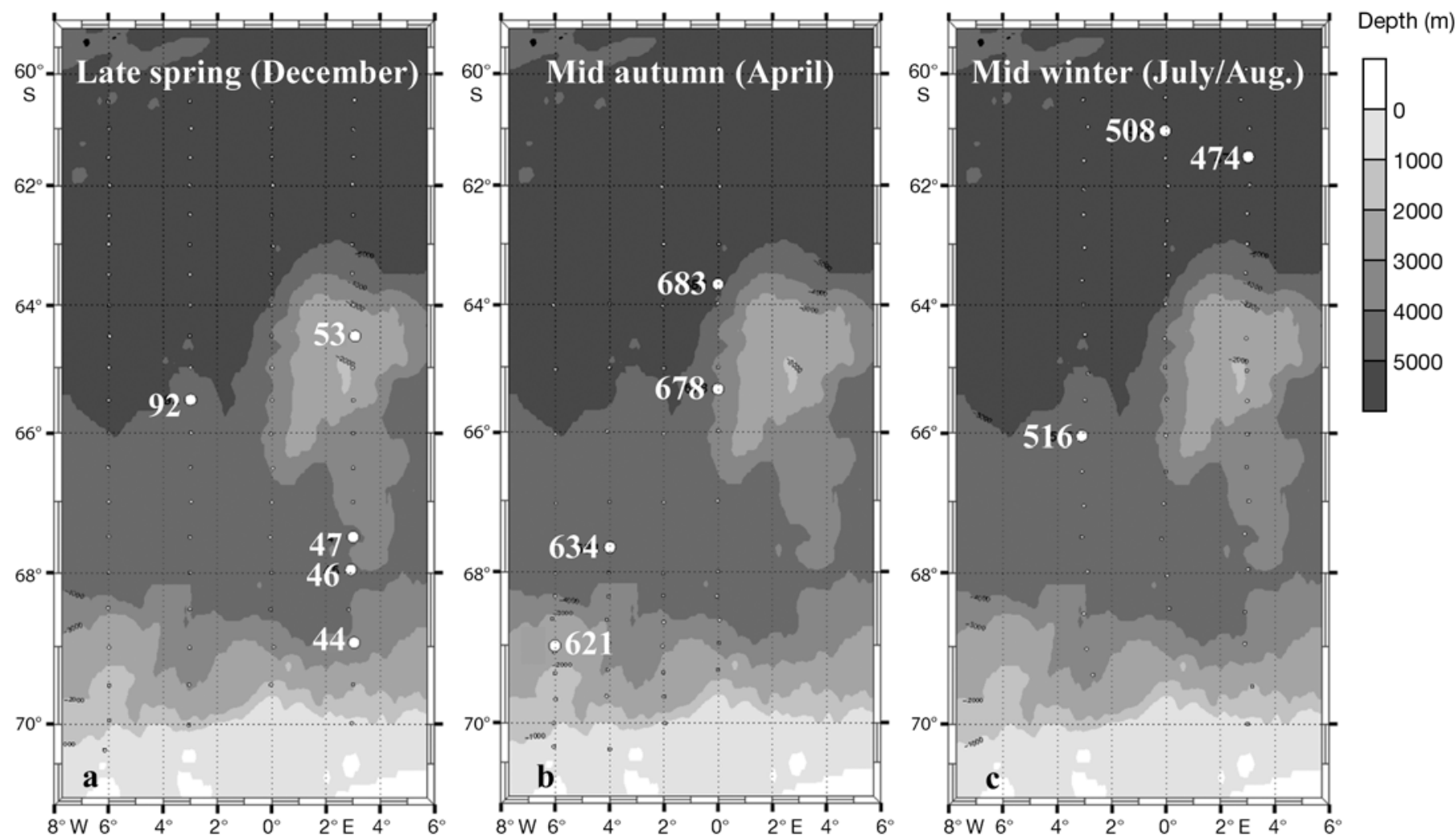

Fig. 2. Station grid (small dots) and stations in the Lazarev Sea at which krill were caught (large white dots) in late spring (December), mid autumn (April) and winter (July to mid August) 
In the different seasons, the chlorophyll a (chl a) concentration and water temperature in the upper $30 \mathrm{~m}$ of the water column were as follows: During the late spring expedition, ice melting was in progress and phytoplankton blooms started to develop in December (Fig. 3). Chl a concentration was highly variable, ranging from 0.2 to $4.8 \mathrm{mg} \mathrm{m}^{-3}$ in 5 to $30 \mathrm{~m}$ depth with $1.0 \mathrm{mg} \mathrm{m}^{-3}$ on average. In autumn, sea ice formation had already started and the ice edge was located at $68^{\circ} \mathrm{S}$. The chl a concentration ranged from 0.06 to $0.5 \mathrm{mg} \mathrm{m}^{-3}$. During the winter cruise, the whole study area from 60 to $70^{\circ} \mathrm{S}$, was covered by sea ice and chl a concentrations in the water column were very low, ranging from 0.01 to $0.04 \mathrm{mg} \mathrm{m}^{-3}$. The mean seawater temperature was $-1.5 \pm$ $0.3^{\circ} \mathrm{C}$ in late spring, $-1.4 \pm 0.4^{\circ} \mathrm{C}$ during the autumn survey, and $-1.8 \pm 0.1^{\circ} \mathrm{C}$ during winter.

Krill sampling and processing. Krill were collected using a RMT8+1 (Rectangular Midwater Trawl) in the

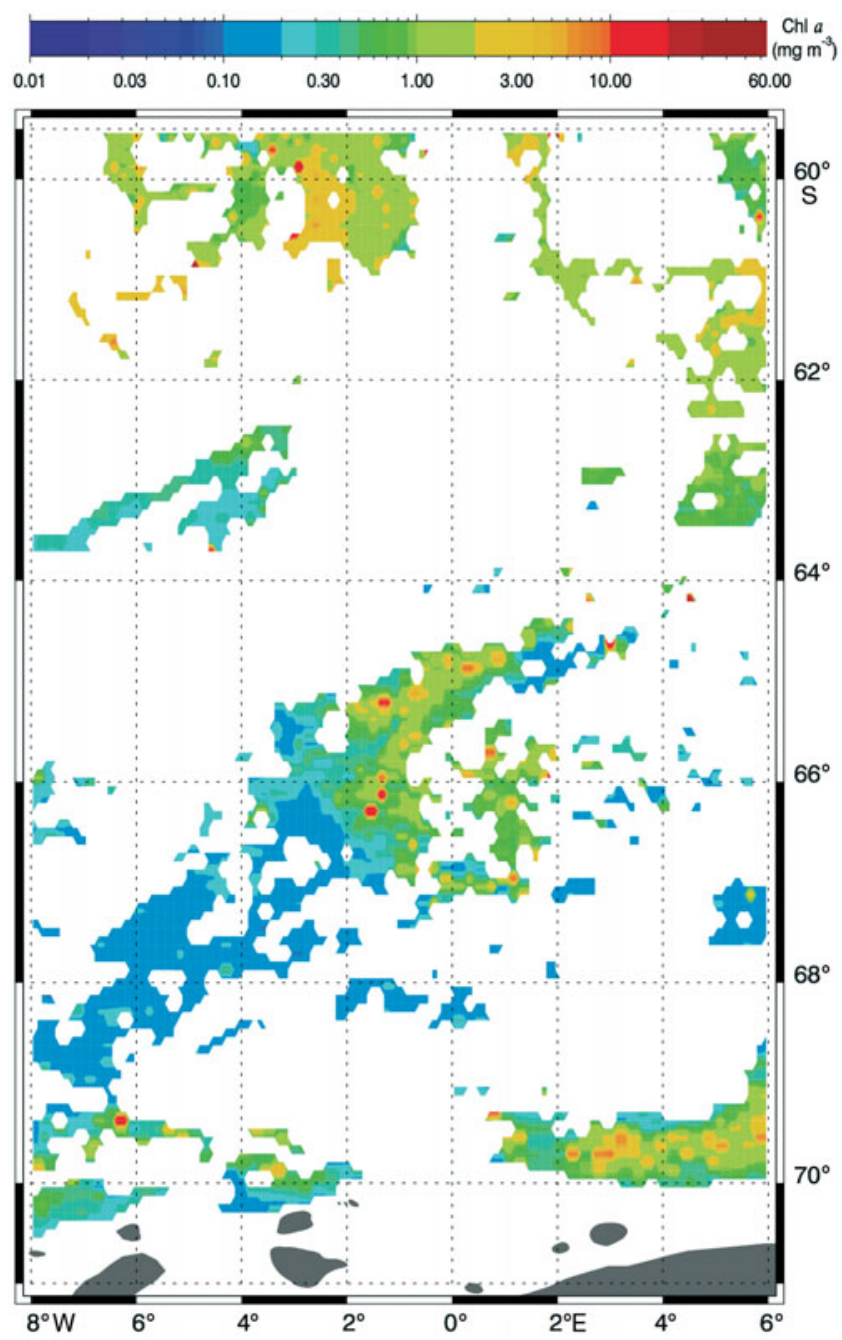

Fig. 3. Monthly mean SeaWiFS (Sea-viewing Wide Fieldof-view Sensor) chlorophyll a values $\left(\mathrm{mg} \mathrm{m}^{-3}\right)$ in December 2005. White: no data top $50 \mathrm{~m}$ of the water column. The net was equipped with a 201 (RMT8) and 101 (RMT1) closed cod end to collect krill in suitable condition for ecophysiological experiments and analyses.

Immediately after the haul, one fraction of subadult and adult krill (staged after Siegel 1987) was used to measure metabolic rates (oxygen uptake, ammonium production), growth rates (only late spring and winter), and feeding activity. From the remaining animals, body length and size and colour of the DG (only late spring and winter) were recorded before snap-freezing in liquid nitrogen and storage at $-80^{\circ} \mathrm{C}$ for analysis of dry mass, elemental (carbon, nitrogen) and biochemical composition (total body lipid and protein), as well as activity of metabolic enzymes (CS: citrate synthase, $\mathrm{MDH}$ : malate dehydrogenase and HOAD: 3-hydroxyacyl-CoA dehydrogenase).

The total length of krill (mm) was measured from the front of the eye to the tip of the telson. The carapace length was measured from the tip of the rostrum to the posterior notch of the carapace, whereas the DG was measured through the carapace along its longest axis (Nicol et al. 2004).

Analysis of dry mass and body composition (carbon, nitrogen, protein and lipid content). After lyophilisation for $24 \mathrm{~h}$, individual krill were weighed and ground to a powder in liquid nitrogen. For analyses of carbon (C) and nitrogen $(\mathrm{N})$, aliquots of 0.2 to $0.5 \mathrm{mg}$ from each krill homogenate was analysed as described elsewhere (Meyer et al. 2002a, 2003). For determination of total body protein in krill, the BIO-RAD DC Protein Assay was used, which is a modification of the Lowry et al. (1951) assay. For this assay, another aliquot of powder (2mg) was incubated in $1 \mathrm{ml} 1 \mathrm{~N} \mathrm{NaOH}$ for $2 \mathrm{~h}$ at $60^{\circ} \mathrm{C}$, then diluted to $0.5 \mathrm{~N} \mathrm{NaOH}$ and centrifuged at $2000 \mathrm{~g}$ for $5 \mathrm{~min}$. The supernatant was used for determination of protein content, using a microplate reader (Bio-TEK Synergy HT). The standard curves were prepared with bovine serum albumin in $0.5 \mathrm{~N} \mathrm{NaOH}$. This method is appropriate for determination of the total body protein content in krill. The method of Bradford (1976) underestimates the protein level in krill up to 3-fold. Lipids were extracted from 10 to $15 \mathrm{mg}$ of krill homogenate in dichloromethane/methanol (2:1 v/v) and total lipid content was determined gravimetrically (Hagen 2000).

Measurements of metabolic rates. The rates of oxygen consumption and ammonium excretion were measured by incubating individual krill in 2.51 sealed glass bottles with filtered seawater $\left(0.2 \mu \mathrm{m}\right.$ pore size, $\left.0^{\circ} \mathrm{C}\right)$. In each experiment, 4 bottles containing krill and 3 control bottles without krill were used. All experimental bottles were incubated at $0^{\circ} \mathrm{C}$ for 12 to $24 \mathrm{~h}$ in a water bath located in a constant temperature room. After incubation, subsampling was carried out by rapidly in- 
serting a glass tube attached to a silicon tube and siphoning the mixed contents of the bottles into $50 \mathrm{ml}$ Winkler bottles for oxygen determination according to Atkinson et al. (2002) and into $15 \mathrm{ml}$ Falken tubes for analysis of ammonium content. For oxygen and ammonium determination, 3 replicate subsamples were taken from each experimental bottle. Oxygen concentration was determined after immediate fixing for Winkler titrations, as described by Meyer et al. (2002a), using a 702 SM Titrino (Metrohm). In all experiments, individual krill were freely swimming in the incubation bottles and the decrease in oxygen concentration was $<10 \%$, which is not believed to effect krill behaviour and hence respiration rates (Johnson et al. 1984). Ammonium concentration was analysed photometrically by the phenol-hypochlorite method, according to Solorzano (1969).

Determination of the activities of metabolic enzymes. $\mathrm{CS}$ and $\mathrm{MDH}$ were measured to estimate metabolic activity, and HOAD was measured to estimate the metabolic flux of catabolism of storage lipids. Both CS and $\mathrm{MDH}$ catalyze reactions in the citric acid cycle, serving as proxies for aerobic potential. $\mathrm{MDH}$, however, also plays other roles, such as shunting electrons between the cytosol and mitochrondrion, and might therefore better represent overall metabolism. HOAD is a key enzyme of $\beta$-oxidation of fatty acids and therefore a good proxy of the utilisation of body lipids (Auerswald \& Gäde 1999). A detailed description of the rationale of this selection, as well as the function and position of these enzymes in the respective metabolic pathways, is given in Auerswald et al. (2009).

Tissue preparation. The fifth abdominal segment (AS) of frozen animals was dissected carefully for determination of the activities of the metabolic enzymes $\mathrm{CS}$ and $\mathrm{MDH}$, whereas the hepatopancreas region (HR) was used for the determination of HOAD. In adult krill, this region is important for lipid storage, where lipid turnover is high. All dissections took place on a cooling element to avoid thawing. The HR and AS were homogenised in a pre-weighed and pre-cooled glass potter (Tissue grind pestle, Kontes Glass Company, US) in ice-cold deionised water at a concentration of $100 \mathrm{mg}$ fresh weight $\left(\mathrm{f}_{\mathrm{w}}\right) \mathrm{ml}^{-1}$, which corresponds to a dilution of 1:10. Aliquots of 50 to $150 \mu \mathrm{l}$ of the homogenised tissues were transferred into new reaction tubes, dipped in liquid nitrogen and stored at $-80^{\circ} \mathrm{C}$ until analysis of enzyme activities within $1 \mathrm{wk}$.

Enzyme assays. Before measuring the activity of the metabolic enzymes, the frozen samples were defrosted gently on ice and centrifuged at $5000 \mathrm{~g}$ and $4^{\circ} \mathrm{C}$ for $10 \mathrm{~min}$. The supernatants were used to determine the enzyme activity and the corresponding protein content for calculation of specific enzyme activity (per g protein, $\left.g_{\text {prot }}\right)$. The protein content was measured with the
BIO-RAD Protein assay, based on the method of Bradford (1976), for comparison with the majority of enzyme studies and due to the sensitivity of this method for soluble proteins at low concentrations.

MDH (EC 1.1.1.37): In a semi-microcuvette, $810 \mu \mathrm{l}$ reaction buffer (0.1 $\mathrm{M}$ potassium phosphate, $\mathrm{pH}$ 7.0), $30 \mu \mathrm{l}$ nicotinamide adenine dinucleotide, reduced form (NADH, $7 \mathrm{mM}$ in Milli-Q Sigma N8129), and $30 \mu \mathrm{l}$ sample extract (diluted 1:50 with the reaction buffer, see above) were mixed. After $5 \mathrm{~min}$ of pre-incubation at $25^{\circ} \mathrm{C}$, the reaction was initiated by adding $30 \mu \mathrm{l}$ oxaloacetate (12 $\mathrm{mM}$ in Milli-Q). The change in absorbance at $340 \mathrm{~nm}$ was recorded for $5 \mathrm{~min}$. The conversion of $1 \mu \mathrm{M}$ substrate per $\mathrm{g}_{\text {prot }}$ and min to $\mathrm{U}_{\mathrm{p}_{\text {prot }}}{ }^{-1}$ $\mathrm{min}^{-1}$ was carried out using the extinction coefficient of $\varepsilon_{340}=6.22 \mathrm{mM}^{-1} \mathrm{~cm}^{-1}$.

CS (EC 4.1.3.7.): CS activity was determined according to Stitt (1984) using the modifications described by Meyer et al. (2002b). To a semi-microcuvette filled with $780 \mu \mathrm{l} 0.5 \mathrm{M}$ Tris/HCl-buffer $(\mathrm{pH} 8$, supplemented with $0.1 \mathrm{M} \mathrm{KCl}$ and $1 \mathrm{mM}$ EDTA), we added $30 \mu \mathrm{L}$ DTNB (5, 5' -dithiobis(2-nitrobenzoic acid), $6 \mathrm{mmol} \mathrm{l}^{-1}$ in buffer, Sigma D8130), $20 \mu$ acetyl-CoA (acetyl-coenzyme A tri-lithium salt, 6 mM, Roche Diagnostics 101907) and $30 \mu \mathrm{l}$ sample. After $5 \mathrm{~min}$ of incubation at $30^{\circ} \mathrm{C}$, the reaction was initiated by adding $20 \mu \mathrm{l}$ oxaloacetic acid (12 mM, Sigma O 4126) and monitored continuously at $412 \mathrm{~nm}$ for 3 to $5 \mathrm{~min}$. The molecular turnover was expressed as $\mathrm{U} \mathrm{g}_{\text {prot }}{ }^{-1} \mathrm{~min}^{-1}$ using the extinction coefficient of $\varepsilon_{412}=13.6 \mathrm{mM}^{-1} \mathrm{~cm}^{-1}$.

HOAD (EC 1.1.1.35): The activity of HOAD was determined according to Auerswald and Gäde (1999). In brief: to a semi-microcuvette, $810 \mu \mathrm{l}$ TRA (triethanolamine)/HCl buffer (107 mM, pH 7, supplemented with $5.3 \mathrm{mM}$ EDTA) and $30 \mu \mathrm{l}$ sample were added and mixed. The reaction was initiated with $30 \mu \mathrm{l}$ acetoacetyl-CoA (Sigma A-1625) and monitored photometrically at $340 \mathrm{~nm}$ and $25^{\circ} \mathrm{C}$ for $5 \mathrm{~min}$. The activity of HOAD was calculated as described for $\mathrm{MDH}$ (see above).

Activation energy of the metabolic enzymes. The activation energy $\left(E_{\mathrm{a}}\right)$ of $\mathrm{MDH}, \mathrm{CS}$ and HOAD was calculated in order to transform their activity assayed at the different temperatures in the laboratory to the in situ enzyme activity at field temperature. $E_{\mathrm{a}}$ can be determined from temperature ( $T$ in $\mathrm{K}$ ) and the corresponding enzyme activity (rate constant $=k$ ) by graphing $\ln k$ versus $1 / T$. We measured the activity of $\mathrm{MDH}$, $\mathrm{CS}$ and $\mathrm{HOAD}$ in a sample at different temperatures $\left(30,20,10,2^{\circ} \mathrm{C}\right)$ and determined $E_{\mathrm{a}}$ from the slope of the regression line between $\ln k$ and $1 / T \times 10^{3}(\mathrm{~K})$ for each enzyme (Table 1$)$. The relationship between slope and $E_{\mathrm{a}}$ is: slope $=-E_{\mathrm{a}} / R$, where $R$ is the gas constant (8.31 $\left.\mathrm{J} \mathrm{mol}^{-1} \mathrm{~K}^{-1}\right)$. The enzyme activities were corrected for the in situ temperature by applying the $E_{\mathrm{a}}$ 
Table 1. Regression of the relationship between $1 / T \times 10^{3}(\mathrm{~K})$ vs. $\ln \left(\right.$ enzyme activity) and calculated activation energy $\left(E_{\mathrm{a}}\right)$ of malatdehydrogenase (MDH), citrate synthase (CS), and 3-hydroxyacyl-CoA dehydrogenase (HOAD)

\begin{tabular}{|llcc|}
\hline Enzymes & \multicolumn{1}{c}{ Regression } & $\mathrm{r}^{2}$ & $E_{\mathrm{a}}$ \\
\hline MDH & $y=-7262.6 x+28.3$ & 0.997 & 60.38 \\
CS & $y=-1570.2 x+6.3$ & 0.996 & 13.05 \\
HOAD & $y=-9395.3 x+32.7$ & 0.996 & 78.12 \\
\hline
\end{tabular}

determined for each enzyme (Table 1) to the Arrhenius equation:

$\mathrm{ME}_{\text {situ }}=\mathrm{ME}_{\text {incubation }} \times \exp \left[E_{\mathrm{a}} \times\left(T_{\text {incubation }}-T_{\text {situ }}\right) \times R^{-1}\right]$

where $\mathrm{ME}_{\text {incubation }}$ is enzyme activity at $T_{\text {incubation (assay }}$ temperature in $\mathrm{K}$ ) and $\mathrm{ME}_{\text {situ }}$ is enzyme activity at $T_{\text {situ }}$ (field temperature in $\mathrm{K}$ ).

Feeding experiments. The experiments were performed in the same way as described in detail previously (Atkinson et al. 2002). In brief, to determine the feeding activity in the different seasons, 4 krill were incubated in 601 containers filled with surface seawater enriched with various concentrations of algae obtained from melted brown discoloured chunks of multiyear ice (Table 2). In each season, 4 containers with krill and 3 control containers without krill were used. The animals were acclimated for $24 \mathrm{~h}$ in the same food concentrations prior to the start of the feeding experiment and the different food concentrations for each experiment were determined in terms of chl a.

At the start of each experiment and after $24 \mathrm{~h}$ incubation, 3 samples of $250 \mathrm{ml}$ were taken for chl a analysis from each container, as described elsewhere (Atkinson et al. 2002), and analysed according to Meyer et al. (2002a). In the feeding experiments, no significant changes in chl a concentration were detected in controls, so we calculated the clearance rates of the total phytoplankton biomass in each tank as follows (Båmstedt et al. 2000):

$$
F=\ln \left(C_{\mathrm{c}} / C_{\mathrm{k}}\right) V / m_{\mathrm{k}} t
$$

where $F$ is the clearance rate $\left(\mathrm{ml} \mathrm{mg}^{-1}\right.$ body $\left.\mathrm{C} \mathrm{h}^{-1}\right), C_{\mathrm{c}}$ is the initial concentration in the tanks, $C_{\mathrm{k}}$ is the final concentration in the tanks, $V$ is the volume of the container $(\mathrm{ml}), m_{\mathrm{k}}$ is the body mass $(\mathrm{mg} \mathrm{C})$ of the krill, and $t$ is the experimental duration (h).

Ingestion rates were calculated as the product of the clearance rate of the phytoplankton biomass $\left(\mathrm{ml} \mathrm{mg}^{-1}\right.$ body $\mathrm{C} \mathrm{h}^{-1}$ ) and its initial $\mathrm{C}$ concentration $\left(\mathrm{mg} \mathrm{ml}^{-1}\right)$ and then expressed as a daily $\mathrm{C}$ ration (\% body $\mathrm{C} \mathrm{d}^{-1}$ ) under the assumption that the krill feeding rates reflect the daily average rate. Due to the low chl a concentration of the surface seawater used to prepare the algal mixture for the feeding experiments (late spring:
Table 2. Concentration of algal mixture and mean individual dry mass (DM) of krill used in the feeding experiments

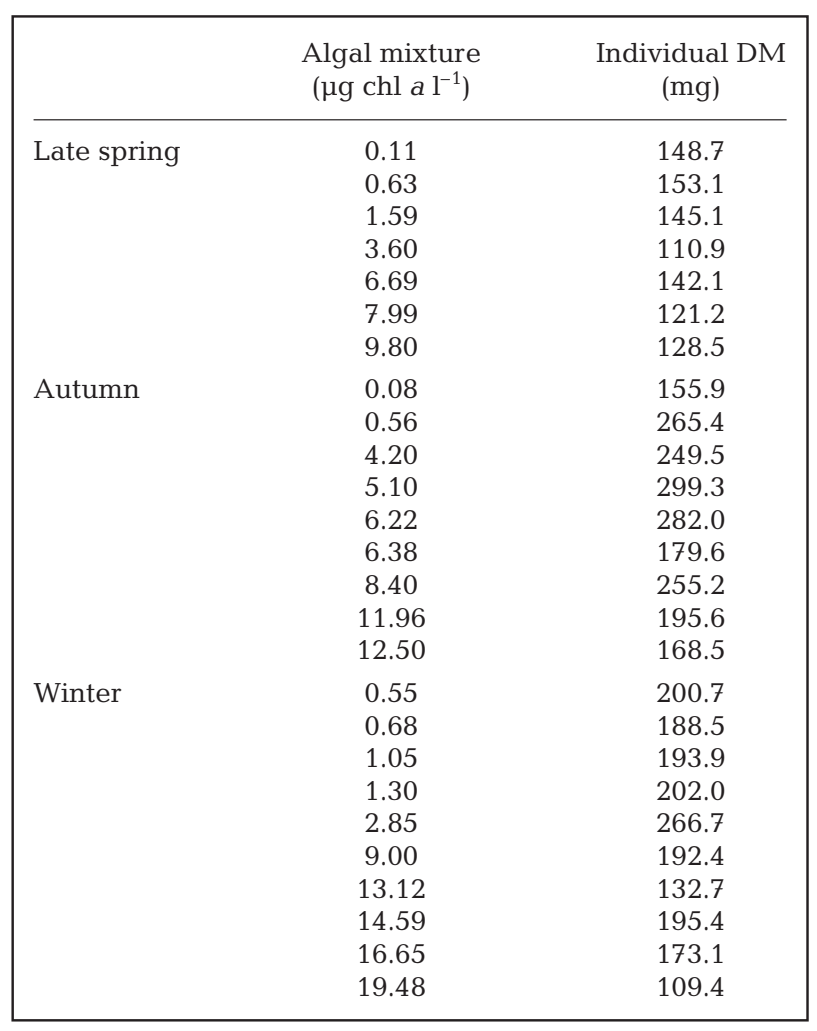

$\leq 0.1 \mathrm{mg} \mathrm{m}^{-3}$, autumn: $\leq 0.08 \mathrm{mg} \mathrm{m}^{-3}$, winter: $\leq 0.02 \mathrm{mg}$ $\mathrm{m}^{-3}$ ), the algae in the incubation container was derived mainly from the melted sea ice. The multiyear ice used for our feeding experiments had a very similar species composition in the different seasons. The algal mixture was dominated by diatoms of the taxon Fragilariopsis spp., followed by large pennate diatoms, small centric diatoms, and Chaetoceros spp. The melted sea ice had chl a concentrations ranging from 80 to $450 \mathrm{mg} \mathrm{m}^{-3}$ and the C:chl a ratios of these algae are reported to be 31 (Palmisano \& Sulivan 1983), 53 (Kang et al. 2001), 48 to 61 (Meyer et al. 2002a), 20 to 40 (Lizotte 2003), or 55 (Garrison et al. 2005). Therefore, in the different seasons, the measured chl a concentrations were converted into $\mathrm{C}$ equivalents using a C:chl a ratio of 50 .

Determination of growth rate and inter-moult period. Growth rates were measured following the Instantaneous Growth Rate (IGR) method outlined by Quetin \& Ross (1991) and modified by Nicol et al. (1992). Freshly caught krill (100 to 129 ind.) were randomly selected and individually placed in 21 plastic jars filled with freshly collected surface seawater. The number of incubated individuals is comparable with previous growth rate studies using the IGR method (e.g. Nicol et al. 1992, Arnold et al. 2004). They were incubated in the jars for 4 to $5 \mathrm{~d}$ in the dark at $0^{\circ} \mathrm{C}$ in a constant tem- 
perature room because the measured growth in the first $5 \mathrm{~d}$ post capture still reflects the field situation (Buchholz 1991, Nicol et al. 1992). The jars were checked twice daily for moults and dead individuals. If the krill had moulted, the individual and the exuvia were removed and the length of the right uropod was measured (when damaged the left uropod was used). The daily moulting frequency $f$ was calculated as:

$$
f=N_{\mathrm{m}} /\left(N_{\mathrm{i}} d\right)
$$

where $d$ is the duration of the experiment in d, $N_{\mathrm{m}}$ is the number of krill that moulted in this time, and $N_{\mathrm{i}}$ is the total number of krill incubated at the start, minus the animals that died during the experiment. The intermoult period (IMP) is the inverse of the moulting frequency. The Growth Increment (GI) on moulting $\left(\%\right.$ growth $\mathrm{IMP}^{-1}$ ) was defined as the percentage difference between the length of the right uropod (when damaged the left uropod was used) on the newly moulted animal $\left(U_{\mathrm{a}}\right)$ and the moult $\left(U_{\mathrm{m}}\right)$ :

$$
\mathrm{GI}=\left[\left(U_{\mathrm{a}}-U_{\mathrm{m}}\right) / U_{\mathrm{m}}\right] 100
$$

The change in body length (BL) over the IMP was determined from a linear regression of BL of uropod length $U(\mathrm{~mm})$ of the post-moult krill. Length measurements from all experiments in both years were pooled due to insignificant differences between regressions of seasons:

$$
\mathrm{BL}=6.89 U-0.50, \mathrm{r}^{2}=0.96, \mathrm{n}=71, \mathrm{p}<0.001
$$

The growth in $\mathrm{mm} \mathrm{d}^{-1}$ was then calculated as the difference between the premoult and postmoult BL divided by the IMP in d (Daly 2004).

Statistical analysis. Prior to statistical analyses, data were tested for normality. Non-normal data were square-root transformed to achieve a normal distribution (Zar 1999). For testing of significant differences between data groups, a 1-way ANOVA (Model I) was calculated and the Holm-Sidak post-hoc test applied for multiple comparisons. These tests were performed by SigmaStat 3.0 (SPSS). A Type I linear regression was used for all correlations presented, and the difference between regression lines were tested according to Zar (1999) using GraphPad Prism 4. The significance level for all tests was set at $\mathrm{p}<0.05$.

\section{RESULTS}

\section{Krill distribution and population structure in the various seasons}

During the late spring and beginning of summer survey, krill were caught in open waters in the polynya as well as in ice-covered areas. The main krill concentra- tions occurred in the northern part between $61^{\circ}$ and $64^{\circ} \mathrm{S}$ as well as south of $67^{\circ} \mathrm{S}$, extending as a tongue across the southern slopes of Maude Rise. Spatial distribution of krill size groups was not uniform across the survey area. The length composition was dominated by a large fraction of 1 yr old juvenile krill of 17 to $21 \mathrm{~mm}$ modal size. More than $50 \%$ of the population consisted of this size and age group, which was located at stations in the central and northern areas. South of $67^{\circ} \mathrm{S}$, we predominately found medium- to large-sized immature and adult krill, ranging mainly between 27 and $37 \mathrm{~mm}$. The length frequency distribution showed a gap in size classes around $30 \mathrm{~mm}$, the expected modal size of the $2 \mathrm{yr}$ old krill at this time of the year. Larger krill between 30 and $45 \mathrm{~mm}$ were mostly adults and were only observed at some scattered stations in the southern and northern parts of the area. However, almost none of the specimens in the entire population were $>50 \mathrm{~mm}$, although krill of this size regularly occur in the Scotia Sea region. Despite the great dominance of pre-spawning maturity stages, we also found animals in advanced spawning conditions, indicating the onset of the spawning season.

In autumn 2004, major krill concentrations occurred in the northern part between $61^{\circ}$ and $64^{\circ} \mathrm{S}$. Another patch of relatively high krill concentration was found across the survey area just outside the marginal ice zone. The autumn population was clearly dominated by the modal size class of $36 \mathrm{~mm}$. This age class (Age class 2) usually consists of immature specimens that have not yet participated in the spawning process. The juvenile Age class 1, with a mean length of approximately 26 to $28 \mathrm{~mm}$, was almost completely missing during our study. Medium-sized krill, from ca. 28 to $43 \mathrm{~mm}$, were mainly located further offshore. Most of the krill between $61^{\circ}$ and $68^{\circ} \mathrm{S}$ were juveniles or immature stages with a modal length of $34 \mathrm{~mm}$. South of the ice edge $\left(68^{\circ} \mathrm{S}\right)$, the size composition of krill changed markedly. Here, the length composition had a peak around $34 \mathrm{~mm}$ but mainly centred around $47 \mathrm{~mm}$. During the survey, most females were already in postspawning condition, so it can be concluded that spawning ended before late March.

During winter 2006, the net sampling programme took place during a period of complete sea-ice coverage of the survey area. The main krill concentrations occurred in the north-western part between $60^{\circ}$ and $66^{\circ} \mathrm{S}$. The poorest catches were obtained south of $67^{\circ} \mathrm{S}$. The krill population in winter 2006 was dominated by a large fraction of 1 and $2 \mathrm{yr}$ old krill (modal size classes around 25 and $35 \mathrm{~mm}$ ). The smallest size class (26 to $27 \mathrm{~mm}$ ), which represented mainly Age class 1 , was found in the more southern and western areas. In the central part of our study region, we found a mixture of 1 and 2 yr old krill, while in the east, krill had a 
Table 3. Euphausia superba. Body length (BL), dry mass (DM), carbon (C), nitrogen (N) and biochemical body composition of freshly caught krill in different seasons; data are mean $\pm \mathrm{SD}$ (range); n: number of samples. Superscripted letters indicate a significant difference from A: late spring, B: autumn, C: winter

\begin{tabular}{|lccc|}
\hline Measurement & Late spring & Autumn & Winter \\
\hline BL (mm) & $33 \pm 3(30-39)$ & $45 \pm 5(35-52)^{\mathrm{A}, \mathrm{C}}$ & $35 \pm 4(30-45)$ \\
$\mathrm{DM}(\mathrm{mg})$ & $51.3 \pm 12.9(35.2-72.3)$ & $174.7 \pm 24.7(77.5-314.2)^{\mathrm{A}, \mathrm{C}}$ & $74.7 \pm 24.7(36.7-128.5)$ \\
$\% \mathrm{C}(\mathrm{mg} \mathrm{DM})$ & $39.8 \pm 1.4(37.4-42.7)^{\mathrm{B}, \mathrm{C}}$ & $52.2 \pm 3.5(46.4-65.2)^{\mathrm{A}, \mathrm{C}}$ & $49.8 \pm 1.7(45.5-53.2)^{\mathrm{A}, \mathrm{B}}$ \\
$\% \mathrm{~N}(\mathrm{mg} \mathrm{DM})$ & $10.8 \pm 0.4(9.9-11.5)^{\mathrm{B}, \mathrm{C}}$ & $8.3 \pm 0.9(6.6-10.6)^{\mathrm{A}, \mathrm{C}}$ & $9.1 \pm 0.5(8.0-10.2)^{\mathrm{A}, \mathrm{B}}$ \\
C:N & $3.7 \pm 0.2(3.4-4.0)^{\mathrm{B}, \mathrm{C}}$ & $6.4 \pm 0.9(4.7-8.8)^{\mathrm{A}, \mathrm{C}}$ & $5.5 \pm 0.4(4.5-6.7)^{\mathrm{A}, \mathrm{B}}$ \\
\%Lipid (mg DM) & $5.2 \pm 0.7(4.0-6.2)^{\mathrm{B}, \mathrm{C}}$ & $31.9 \pm 5.8(20.6-41.7)$ & $29.6 \pm 3.4(19.5-33.6)$ \\
$\%$ Protein (mg DM) & $46.0 \pm 2.7(40.9-50.3)^{\mathrm{B}, \mathrm{C}}$ & $38.3 \pm 4.6(28.7-51.7)$ & $38.4 \pm 2.8(31.4-44.0)$ \\
$\mathrm{n}$ & 32 & 45 & 24 \\
\hline
\end{tabular}

modal size of ca. $35 \mathrm{~mm}$, which would reflect the dominance of Age class 2 krill. The maturity stage composition showed a clear dominance of subadult (immature) stages. Some males and females were found in the adult resting stage.

During the sampling of krill for the physiological investigations, the specific subareas with their different krill composition characteristics, described above for each season (Fig. 2), were taken into consideration. In late spring, the size range of adult krill used for the experiments and analyses was relatively small, ranging from 30 to $39 \mathrm{~mm}$, whereas autumn krill were $45 \mathrm{~mm}$ on average (Table 3). During winter, all adult krill sampled were immature with a mean length of $35 \mathrm{~mm}$.

\section{Body composition}

The observed seasonal differences in elemental body composition appear to reflect the seasonal build up of extensive lipid stores at the onset of winter (Hagen et al. 2001), because they are C-rich. The C content was lowest in late spring (40\% of dry mass) with higher values in autumn (52\% DM) and winter (50\% DM, Table 3). The $\mathrm{N}$ content, however, was relatively stable throughout the year at approximately $10 \%$ DM (Table 3). As a result of the higher $\mathrm{C}$ content in autumn and winter, the $C: N$ ratios are almost double that in late spring (Table 3). The lipid levels followed the same pattern as the body $\mathrm{C}$ content, with highest values in autumn (32\% DM) and winter krill (30\% DM), and lowest in late spring krill (5\% DM, Table 3). Conversely, protein content was highest in late spring (46\% DM; $38 \%$ DM in both autumn and winter), due to the high lipid content in mid autumn and winter (Table 3).

The relationship between BL and DM is similar for all seasons (Table 4). The same is true for the relationship between DM and $\mathrm{N}$ as well as that between $\mathrm{N}$ and protein, whereas the relationship between DM and C calculated from late spring krill is different from that from autumn and winter krill (Table 4). Body C levels correlate positively with the lipid content, but the relationship between them is different in late spring compared with autumn and winter (Table 4). When plotting C:N ratios against the relative lipid content, it becomes clear that there are major differences between seasons: while there is a relationship in autumn and winter, there is no correlation at all in late spring (Table 4).

\section{Metabolic rates and the activity of the metabolic enzymes CS, MDH and HOAD}

Similarly sized adult krill in the Lazarev Sea showed significant differences in their respiration rates between seasons (Table 5). The oxygen consumption rate of autumn krill was $50 \%$ and that of winter krill only $30 \%$ of that of late spring krill. Correspondingly, the ammonium excretion rates were highest in krill from late spring. In autumn and winter the rates were 55

Table 4. Euphausia superba. Seasonal relationship of body length (BL) and dry mass (DM), DM and carbon (C), DM and nitrogen (N), C and lipid, N and protein, and C:N ratio and \% body lipid (mg DM) of adult krill from the Lazarev Sea. The unit of BL is $\mathrm{mm}$ and that of the other parameters is mg. Data from different seasons were pooled when no significant differences were found; nc: no correlation; $\mathrm{n}=$ number of data points

\begin{tabular}{|llccc|}
\hline Relationship & Season & Equation & $\mathrm{r}^{2}$ & $\mathrm{n}$ \\
\hline BL to DM & All seasons & $\mathrm{DM}=4.0 \times 10^{-4} \mathrm{BL}^{3.41}$ & 0.94 & 105 \\
DM to C & Late spring & $\mathrm{C}=0.29 \mathrm{DM}+4.56$ & 0.78 & 32 \\
& Autumn and winter & $\mathrm{C}=0.55 \mathrm{DM}-3.56$ & 0.98 & 69 \\
DM to N & All seasons & $\mathrm{N}=0.08 \mathrm{DM}+1.08$ & 0.95 & 101 \\
$\mathrm{C}$ to Lipid & Late spring & Lipid $=0.11 \mathrm{C}+0.39$ & 0.76 & 32 \\
& Autumn and winter & Lipid $=0.66 \mathrm{C}-3.56$ & 0.92 & 69 \\
N to Protein & All seasons & Protein $=4.78 \mathrm{~N}-2.58$ & 0.96 & 101 \\
C:N to \% Lipid & Late spring & nc & & 32 \\
& Autumn and winter & \% Lipid $=4.90 \mathrm{C}: \mathrm{N}+1.30$ & 0.73 & 69 \\
\hline
\end{tabular}


Table 5. Euphausia superba. Oxygen consumption rate per individual and per mg dry mass (DM) of krill, ammonium excretion rate and atomic O:N ratio; data are mean $\pm \mathrm{SD}$ (range). Subscripted letters indicate a significant difference from A: late spring, B: autumn, C: winter. n: no. of experiments

\begin{tabular}{|c|c|c|c|c|c|c|}
\hline & $\begin{array}{r}\text { Oxygen } \\
\left(\mu \mathrm{O}_{2} \text { ind }^{-1} \mathrm{~h}^{-1}\right)\end{array}$ & $\begin{array}{l}\text { onsumption } \\
\qquad\left(\mu l \mathrm{O}_{2} \mathrm{mg}^{-1} \mathrm{DM} \mathrm{h}^{-1}\right)\end{array}$ & $\begin{array}{c}\text { Excretion } \\
\left(\mu g \mathrm{~N} \text { ind. } .^{-1} \mathrm{~h}^{-1}\right)\end{array}$ & $\mathrm{O}: \mathrm{N}$ ratio & $\begin{array}{l}\mathrm{DM} \\
(\mathrm{mg})\end{array}$ & $\mathrm{n}$ \\
\hline Late spring & $\begin{array}{c}91.5 \pm 19.0^{\mathrm{B}, \mathrm{C}} \\
(76.6-116.6)\end{array}$ & $\begin{array}{c}0.71 \pm 0.16^{\mathrm{B}, \mathrm{C}} \\
(0.53-1.13)\end{array}$ & $\begin{array}{c}3.7 \pm 1.2^{\mathrm{B}, \mathrm{C}} \\
(1.4-5.4)\end{array}$ & $\begin{array}{c}28 \pm 12^{\mathrm{B}, \mathrm{C}} \\
(15.7-54.9)\end{array}$ & $\begin{array}{l}123.2 \pm 29.1 \\
(63.2-153.1)\end{array}$ & 12 \\
\hline Autumn & $\begin{array}{c}50.3 \pm 15.2^{\mathrm{A}, \mathrm{C}} \\
(24.7-68.6)\end{array}$ & $\begin{array}{c}0.37 \pm 0.04^{\mathrm{A}, \mathrm{C}} \\
(0.31-0.44)\end{array}$ & $\begin{array}{l}0.3 \pm 0.1 \\
(0.1-0.5)\end{array}$ & $\begin{array}{c}15 \pm 4^{\mathrm{A}, \mathrm{C}} \\
(11.1-21.4)\end{array}$ & $\begin{array}{l}137.2 \pm 40.9 \\
(77.8-193.6)\end{array}$ & 13 \\
\hline Winter & $\begin{array}{c}26.3 \pm 13.1^{\mathrm{A}, \mathrm{B}} \\
(9.3-40.3)\end{array}$ & $\begin{array}{c}0.19 \pm 0.04^{\mathrm{A}, \mathrm{B}} \\
(0.13-0.28)\end{array}$ & $\begin{array}{l}0.5 \pm 0.3 \\
(0.1-0.8)\end{array}$ & $\begin{array}{c}66 \pm 26^{\mathrm{A}, \mathrm{B}} \\
(22.9-109.4)\end{array}$ & $\begin{array}{c}140.4 \pm 64.6 \\
(50.0-195.4)\end{array}$ & 18 \\
\hline
\end{tabular}

and $29 \%$, respectively, of late spring rates. The resulting O:N ratio differed significantly between seasons. The highest ratios were found in winter (66), with less than half that value in late spring (28) and only a quarter in autumn (15).

The activities of CS and MDH (Table 6) as proxies for metabolic activity mirror the pattern of the oxygen uptake rates (see previous paragraph). Both enzymes showed their highest activity in krill from late spring, with significantly lower activities in the other seasons. In autumn and winter, respectively, the CS and $\mathrm{MDH}$ activities in krill were 47 and $39 \%$ (CS), and 77 and $66 \%(\mathrm{MDH})$ of those in late spring krill. The enzyme HOAD, an indicator for lipid breakdown (turnover), showed significantly different activities in krill from the late spring and autumn surveys compared with winter krill. In winter, the activities were approximately $400 \%$ higher than those in late spring and autumn (Table 6).

\section{Feeding activity}

The functional response of krill to increasing food supply was significantly different between seasons (Fig. 4, Table 7). Late spring krill displayed a clear

Table 6. Euphausia superba. Seasonal differences in the activity of the metabolic enzymes malatdehydrogenase (MDH), citrate synthase (CS), and 3-hydroxyacyl-CoA-dehydrogenase (HOAD); data are mean $\pm \mathrm{SD}$; $\mathrm{n}$ : number of replicate samples. Metabolic enzyme activities are expressed as $\mathrm{U} \mathrm{g}_{\text {prot }}{ }^{-1}(1 \mathrm{U}=1 \mu \mathrm{mol}$ substrate used per min). Subscripted letters indicate a significant difference from A: late spring, B: autumn, C: winter

\begin{tabular}{|llllc|}
\hline Season & \multicolumn{1}{c}{$\mathrm{CS}$} & $\mathrm{MDH}$ & $\mathrm{HOAD}$ & $\mathrm{n}$ \\
\hline Late spring & $95 \pm 31^{\mathrm{B}, \mathrm{C}}$ & $370 \pm 79^{\mathrm{B}, \mathrm{C}}$ & $0.12 \pm 0.08$ & 8 \\
Autumn & $45 \pm 14$ & $284 \pm 98$ & $0.10 \pm 0.05$ & 15 \\
Winter & $37 \pm 11$ & $245 \pm 34$ & $0.50 \pm 0.36^{\mathrm{A}, \mathrm{B}}$ & 10 \\
\hline
\end{tabular}

functional response with increasing food concentration, with a maximum daily $\mathrm{C}$ ration (DR) of $10 \%$ body $\mathrm{C} \mathrm{d}^{-1}$ at a food concentration of approximately $600 \mu \mathrm{g}$ $\mathrm{C}^{-1}$. In autumn and winter, when krill were exposed to similar food concentrations as in late spring (Table 1), they showed only 20 and $14 \%$ of the equivalent maximum rates determined in late spring (Fig. 4).

The size of the DGs of freshly caught krill reflects the large difference in feeding activity of krill between late spring and winter (Figs. 5 \& 6, Table 7). Krill of similar size (in terms of carapace length) had less than half the DG size in winter $(2.9 \pm 0.5 \mathrm{~mm}, \mathrm{n}=75)$ compared to late spring ( $7.3 \pm 0.9 \mathrm{~mm}, \mathrm{n}=100$, Figs. $5 \& 6)$. During winter in the Lazarev Sea, the majority of the DGs of freshly caught krill showed no colouration or were milky white (Fig. 6c) or pale yellow (Fig. 6d), whereas those of late spring krill were mainly yellow (Fig. 6a) or black-green (Fig. 6b), suggesting that different food sources were used in different seasons.

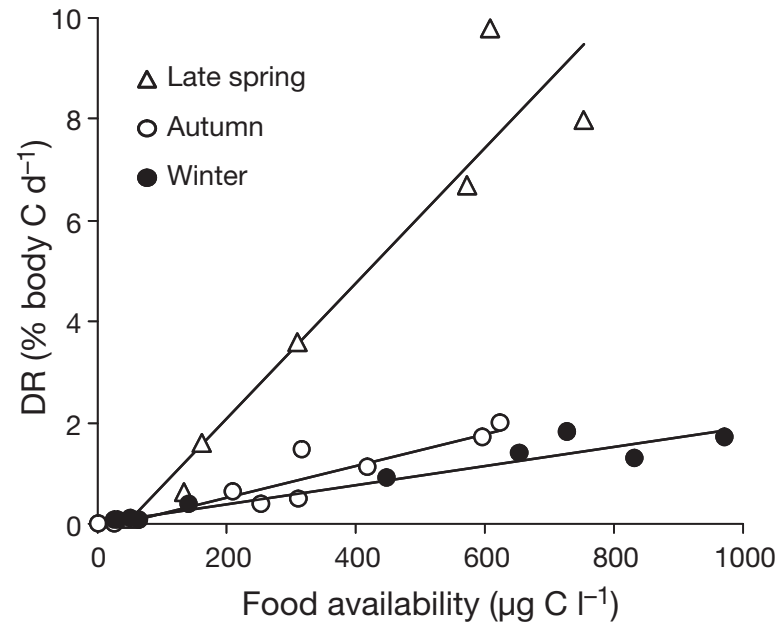

Fig. 4. Euphausia superba. Seasonal daily C ration (DR) as a function of food availability. Data points represent individual experiments. The seasonal linear regressions are shown in Table 7 
Table 7. Euphausia superba. Seasonal linear regressions of daily C ration (DR) in \% body $\mathrm{C} \mathrm{d}^{-1}$ and food availability (FA) in $\mathrm{mg} \mathrm{C} \mathrm{m}^{-3}$, carapace length (CL) and size of digestive glands (DG) in mm, and body dry mass (DM) in mg and oxygen uptake rates (OR) of individual krill in $\mu \mathrm{l} \mathrm{O}$ ind $^{-1} \mathrm{~h}^{-1}$

\begin{tabular}{|lccccc|}
\hline Relationship & Season & Equation & $\mathrm{r}^{2}$ & $\mathrm{n}$ & $\mathrm{p}$ \\
\hline DR to FA & Late spring & $y=0.013 x-0.623$ & 0.91 & 7 & $<0.01$ \\
& Autumn & $y=0.003 x-0.104$ & 0.86 & 9 & $<0.01$ \\
& Winter & $y=0.002 x+0.032$ & 0.93 & 10 & $<0.001$ \\
CL to DG & Late spring & $y=0.47 x+1.26$ & 0.68 & 100 & $<0.001$ \\
& Winter & $y=0.28 x$ & 0.70 & 75 & $<0.001$ \\
DM to OR & Late spring & $y=0.74 x$ & 0.97 & 15 & $<0.001$ \\
& Autumn & $y=0.37 x$ & 0.94 & 15 & $<0.001$ \\
& Winter & $y=0.19 x$ & 0.91 & 20 & $<0.001$ \\
\hline
\end{tabular}

\section{DISCUSSION}

The present study aimed to analyse physiological parameters of Antarctic krill in different seasons in the Lazarev Sea with a comprehensive suite of methods in order to better understand their overwintering in the Southern Ocean. The major conclusions from our results are: (1) Krill strongly reduced oxygen uptake rates to $50 \%$ in autumn and only $30 \%$ in winter of those measured in late spring. (2) The feeding activity of adult krill was only $20 \%$ in autumn and $14 \%$ in winter of late spring rates at similar food concentrations. (3) In winter, krill displayed a flexible (omnivorous) feeding activity. (4) Adult krill showed very low posi-

\section{Growth}

The growth rates of krill from both late spring and winter followed the overall pattern of metabolic activity for these seasons. Growth was positive in both seasons, but significantly lower in winter than in late spring (Table 8). The IMP of late spring krill was approximately half of that of winter krill (Table 8). The variations in growth rates in both seasons are given in Fig. $7 \mathrm{a}-\mathrm{d}$. In late spring, growth rate ranged from 0.03 to $0.10 \mathrm{~mm} \mathrm{~d}^{-1}$ and GIs from 4 to $9 \% \mathrm{IMP}^{-1}$. In winter, the growth rates ranged from 0.0003 to $0.0024 \mathrm{~mm} \mathrm{~d}^{-1}$ and GIs from 0.5 to $3.8 \% \mathrm{IMP}^{-1}$. The chl a concentration in the upper $30 \mathrm{~m}$ of the water column was highly variable in late spring, ranging from 0.2 to $2.2 \mathrm{mg} \mathrm{m}^{-3}$ (Table 8), resulting in a high variability of growth rates between stations (Fig. 7a,b). In winter, the chl a concentrations were more or less uniform at an extremely low level, ranging in mean from 0.01 to $0.04 \mathrm{mg} \mathrm{m}^{-3}$. Consequently, there was no significant variation in growth rates between stations (Fig. ${ }_{7 \mathrm{c}} \mathrm{d}$ ).

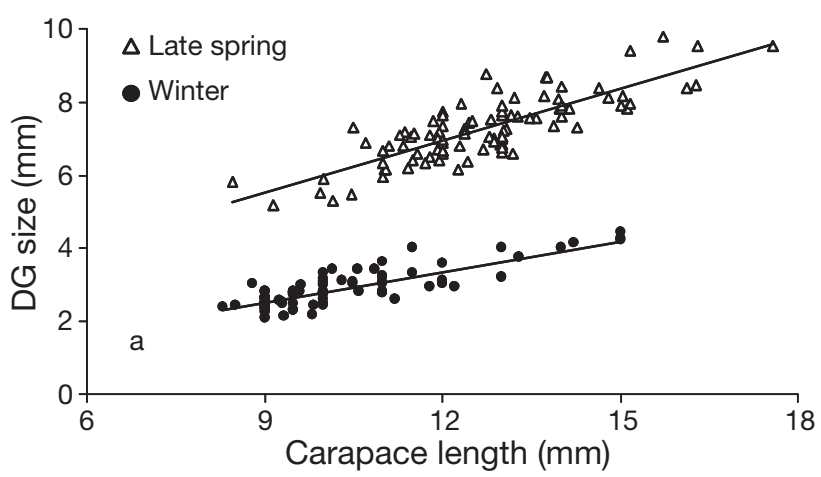

Fig. 5. Euphausia superba. Relationship of carapace length and size of digestive glands (DG) of krill from 3 stations in late spring and 2 stations in winter. The linear regressions are shown in Table 7 tive growth during winter and no shrinkage. (5) In addition to the low feeding activity, adult krill used mainly body lipids and, to a moderate extent, body protein for energy provision during winter. Food intake (at low levels) during winter seems to be an important energy input for krill to survive the winter season.

Below, we discuss our findings with regard to proposed overwintering mechanisms for adult krill, with reference to previous studies of krill overwintering in other regions of the Southern Ocean (Table 9, Fig. 1).

\section{Adaptation of physiological functions for overwintering}

Unlike water temperature, which remains within a narrow range throughout the year, photoperiod and light intensity are environmental parameters with strong seasonality. The scarce amount of daylight at this high latitude and the extensive sea ice coverage in winter rigorously limit primary production and hence the krill food resources. The low food supply during winter is thought to induce reduced feeding rates and subsequent starvation which, in turn, causes the slowdown of physiological functions such as metabolism and growth, or even shrinkage (Quetin \& Ross 1991, Ettershank 1983).

\section{Oxygen uptake rates}

In the Lazarev Sea, metabolic rates were $50 \%$ in autumn and $30 \%$ in winter of rates measured in late spring (Table 5). The majority of published data on oxygen uptake rates are from the late spring and summer season, and data from autumn and winter are rare. Our weight-specific respiration rates measured in krill from late spring (0.5 to $1.1 \mu \mathrm{O}_{2} \mathrm{mg}^{-1} \mathrm{DM} \mathrm{h}^{-1}$, Table 5) are in a comparable range with previous results (Kils 1978: 0.9 to 1.1, Rakusa-Suszczewski \& Opalinski 

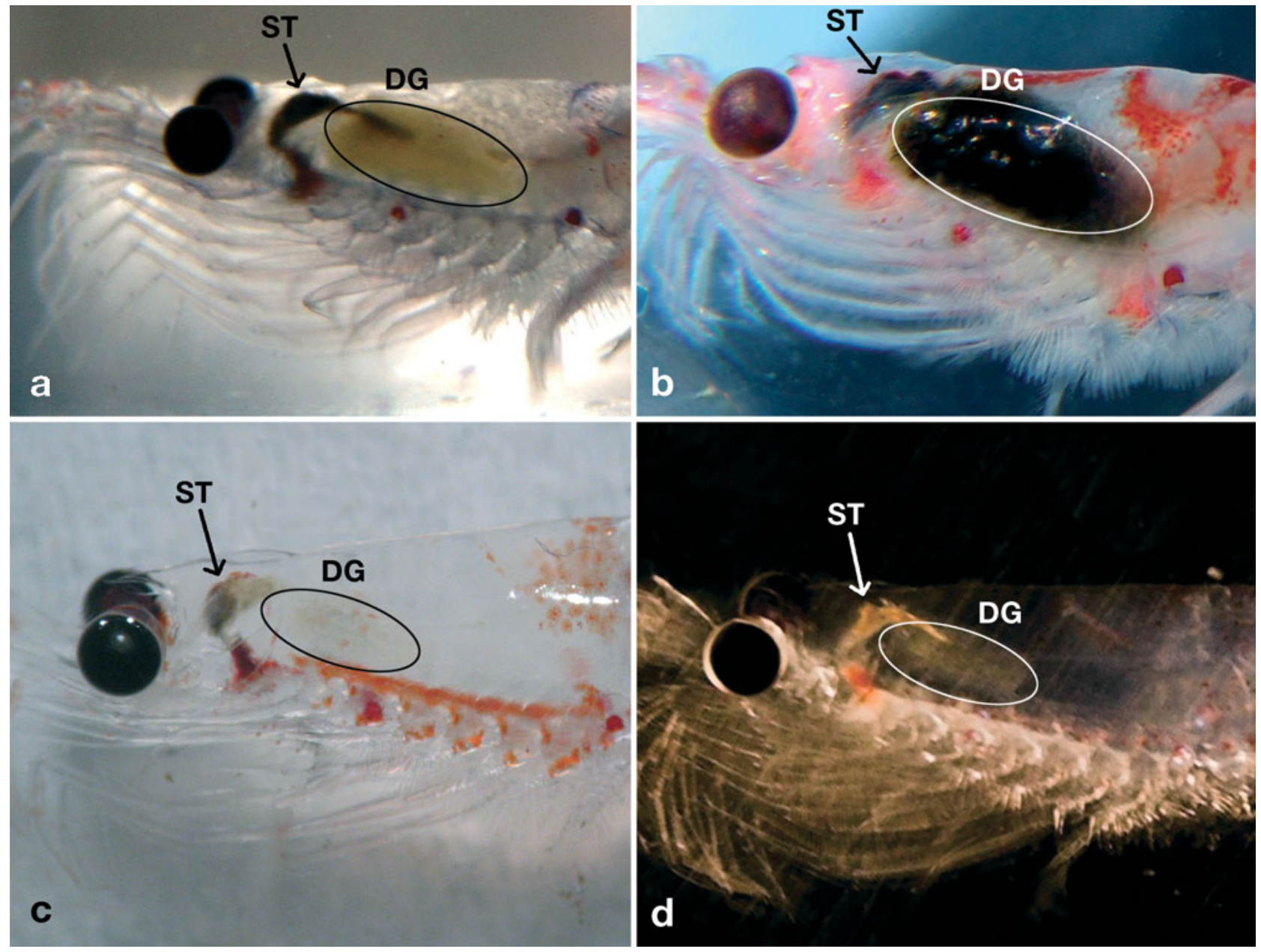

Fig. 6. Euphausia superba. Carapace with digestive gland (DG) and stomach (ST) of freshly caught adult krill; (a) yellow and (b) green-black DG in late spring, and (c) milky white and (d) pale yellow DG in winter. Photos (a) and (d) by A. Hayden and H. Flores, respectively

Table 8. Euphausia superba. Mean growth and intermoult period (IMP) given as growth increment (GI: \% change in uropod length on moulting) and daily growth rate. The range of data in both seasons is given in Fig. 7 ; n: number of moulted individuals. Chl a concentrations and environmental temperature (EVT) are from the upper $30 \mathrm{~m}$ of the water column. Krill length is the mean in each experiment

\begin{tabular}{|lccccccc|}
\hline Stn & $\begin{array}{c}\text { Krill } \\
\text { length } \\
(\mathrm{mm})\end{array}$ & $\begin{array}{c}\text { EVT } \\
\left({ }^{\circ} \mathrm{C}\right)\end{array}$ & $\begin{array}{c}\mathrm{Chl} \mathrm{a} \\
\left(\mathrm{mg} \mathrm{m}^{-3}\right)\end{array}$ & $\mathrm{n}$ & $\begin{array}{c}\text { IMP } \\
\left(\mathrm{d}^{-1}\right)\end{array}$ & $\begin{array}{c}\text { GI }(\%) \\
\left(\mathrm{mm} \mathrm{d}^{-1}\right)\end{array}$ \\
\hline \multicolumn{2}{l}{ Late spring } \\
44 & 37 & -1.71 & 0.19 & 10 & 50 & 4.9 & 0.0737 \\
46 & 36 & -1.57 & 0.27 & 9 & 42 & 6.4 & 0.0556 \\
47 & 30 & -1.58 & 0.24 & 10 & 43 & 7.5 & 0.0713 \\
92 & 41 & -0.84 & 2.17 & 12 & 34 & 7.7 & 0.1036 \\
Winter & & & & & & & \\
474 & 35 & -1.84 & 0.04 & 8 & 102 & 2.4 & 0.0013 \\
508 & 33 & -1.86 & 0.04 & 8 & 77 & 2.3 & 0.0014 \\
516 & 33 & -1.77 & 0.03 & 14 & 55 & 1.5 & 0.0014 \\
\hline
\end{tabular}

1978: 0.4 to 0.7, Ikeda \& Mitchell 1982 and Ikeda \& Bruce 1986: 0.4 to 0.6, Hirche 1983: 0.6, Kawaguchi et al. 1986: 0.4 to 0.7 , Torres et al. 1994a: 0.6 to $0.7 \mu l \mathrm{O}_{2}$ $\mathrm{mg}^{-1} \mathrm{DM} \mathrm{h}^{-1}$ ). In autumn, oxygen uptake rates similar to ours $\left(0.3\right.$ to $\left.0.4 \mu \mathrm{O}_{2} \mathrm{mg} \mathrm{DM} \mathrm{h} \mathrm{D}^{-1}\right)$ were reported by Kawaguchi et al. (1986) from Lütow-Holm Bay (0.2 to $0.6 \mu \mathrm{O} \mathrm{O}_{2} \mathrm{mg}^{-1} \mathrm{DM} \mathrm{h}^{-1}$ ) and Atkinson et al. (2002) from the Lazarev Sea $\left(0.3\right.$ to $\left.0.4 \mu \mathrm{O}_{2} \mathrm{mg}^{-1} \mathrm{DM} \mathrm{h}^{-1}\right)$. The winter values reported from the Western Antarctic Peninsula (WAP, Quetin \& Ross 1991), Southern ScotiaNorthern Weddell Sea region (Torres et al. 1994a), and Lützow-Holm Bay (Kawaguchi et al. 1986), are in line with our data, namely $30 \%$ of summer rates.

\section{Feeding activity}

The metabolic slow-down in autumn and winter was accompanied by low feeding activity: Maximum feed- 
ing activity on natural food assemblages was $20 \%$ in autumn and $14 \%$ in winter of rates measured in late spring (Fig. 4) and summer (Atkinson \& Snÿder 1997). Similarly low feeding activity in autumn was observed in a previous study in the Lazarev Sea (Atkinson et al. 2002). In addition, seasonal feeding studies at the WAP determined a feeding activity in winter of only $2 \%$ of that observed in summer (Quetin \& Ross 1991). Stomach, gut and DG fullness and size can be used as indicators for feeding activity in the field (Morris et al. 1983, Morris \& Priddle 1984, Nicol et al. 2004). In the Lazarev Sea, the DG size of winter krill was less than half that of late spring krill, pointing to a low feeding activity in the field (Nicol et al. 2004). This is consistent with overwintering studies which found low stomach and/or gut contents in krill (Table 9: Morris \& Priddle 1984, Kawaguchi et al. 1986, Lancraft et al. 1991, Daly \& Macaulay 1991, Hopkins et al. 1993, Nishino \& Kawamura 1994).

\section{Individual growth}

The low feeding activity in the Lazarev Sea during winter was accompanied by low individual growth rates in krill (Fig. 7). Shrinkage of krill has also been documented in the Bransfield Strait during winter (Quetin \& Ross 1991), and other authors have hypothesised that krill do not grow in winter (Ikeda 1985, Ikeda \& Thomas 1987). Ikeda \& Dixon (1982) were the first to propose, from laboratory experiments, that shrinkage in response to starvation is a possible overwintering mechanism for krill. Previous studies measuring growth using traditional length-frequency analysis also reported similar results to ours, i.e. nearly zero or low growth during winter (Mackintosh 1972, Stepnik 1982, Morris \& Priddle 1984, Kawaguchi et al. 1986, Siegel 1987, Buchholz et al. 1989) as well as shrinkage (Ettershank 1983). However, determining shrinkage of krill with length-frequency analysis on a population level is problematic. Different size structures of krill within a population might occur due to selective size mortality (predation) and/or selective size immigration/emigration (exchange of water masses). In our winter study, individual growth rates were clearly positive and, at each moult, the krill increased in length by 0.5 to $3.8 \%$. The average daily growth rates, however, were very low due to the longer IMP in winter compared to late spring values (Table 8). Although published data suggest that postlarval krill might be able to shrink in the field during winter, our results indicate that such behaviour may not be the rule but rather the exception

Table 9. Euphausia superba. Studies which examined overwintering mechanisms in the Southern Ocean

\begin{tabular}{|c|c|c|c|}
\hline Region & Results & Study period & Source \\
\hline $\begin{array}{l}\text { Northern Weddell Drift, Scotia Sea, } \\
\text { Eastwind drift (Pacific sector) }\end{array}$ & Zero to low growth & $\begin{array}{l}\text { June-August 1925-1927, } \\
\text { 1923-1939, 1950-1951 }\end{array}$ & Mackintosh (1972) \\
\hline $\begin{array}{l}\text { Admiralty Bay (King George Island, } \\
\text { South Shetland Islands) }\end{array}$ & Low growth & May-July 1979 & Stepnik (1982) \\
\hline Off South Georgia & Low feeding and growth activity & August-September 1983 & Morris \& Priddle (1984) \\
\hline Lütz-Holm Bay (Ongul Islands) & $\begin{array}{l}\text { Low feeding activity (on sediments) } \\
\text { Reduced oxygen consumption rates }\end{array}$ & May-November 1984 & Kawaguchi et al. (1986) \\
\hline $\begin{array}{l}\text { Western Antarctic Peninsula } \\
\text { (Bransfield Strait, north of South } \\
\text { Shetland Islands) }\end{array}$ & $\begin{array}{l}\text { Shrinkage } \\
\text { Lipid utilisation } \\
\text { Reduced oxygen consumption rates } \\
\text { Low feeding activity }\end{array}$ & $\begin{array}{l}\text { March and April 1985, } \\
\text { August and September } \\
1985 \\
\text { January and July } 1987\end{array}$ & Quetin \& Ross (1991) \\
\hline $\begin{array}{l}\text { Southern Scotia Sea/Northern } \\
\text { Weddell Sea region }\end{array}$ & $\begin{array}{l}\text { Low feeding activity } \\
\text { Reduced oxygen consumption rates } \\
\text { Lipid utilisation }\end{array}$ & March 1986, June-August 1988 & $\begin{array}{l}\text { Daly \& Macaulay (1991) } \\
\text { Torres et al. (1994a), } \\
\text { Torres et al. (1994b) }\end{array}$ \\
\hline Southern Scotia Sea & $\begin{array}{l}\text { Low feeding activity } \\
\text { Omnivory }\end{array}$ & June-August 1988 & $\begin{array}{l}\text { Lancraft et al. (1991), } \\
\text { Hopkins et al. (1993) }\end{array}$ \\
\hline $\begin{array}{l}\text { Western Antarctic Peninsula } \\
\text { (Gerlache Strait, Crystal Sound) }\end{array}$ & $\begin{array}{l}\text { Intense feeding on zooplankton } \\
\text { organisms }\end{array}$ & $\begin{array}{l}\text { December 1991-January 1992, } \\
\text { July-August } 1992\end{array}$ & Huntley et al. (1994) \\
\hline South Georgia area & $\begin{array}{l}\text { Low feeding activity } \\
\text { Carnivory }\end{array}$ & July-August 1992 & $\begin{array}{l}\text { Nishino \& Kawamura } \\
\text { (1994) }\end{array}$ \\
\hline $\begin{array}{l}\text { Northern Antarctic Peninsula, } \\
\text { Eastern and western Weddell Sea } \\
\text { and Lazarev Sea }\end{array}$ & Lipid utilisation & $\begin{array}{l}\text { October and November 1983, } \\
\text { January and February 1985, July } \\
\text { and August 1986, October and } \\
\text { November 1986, April and May } 1992\end{array}$ & Hagen et al. (2001) \\
\hline Lazarev Sea & $\begin{array}{l}\text { Reduced oxygen consumption rates } \\
\text { Very low growth rates } \\
\text { Low feeding activity } \\
\text { Lipid utilisation }\end{array}$ & $\begin{array}{l}\text { April 2004, December 2005, } \\
\text { July and August } 2006\end{array}$ & Present study \\
\hline
\end{tabular}



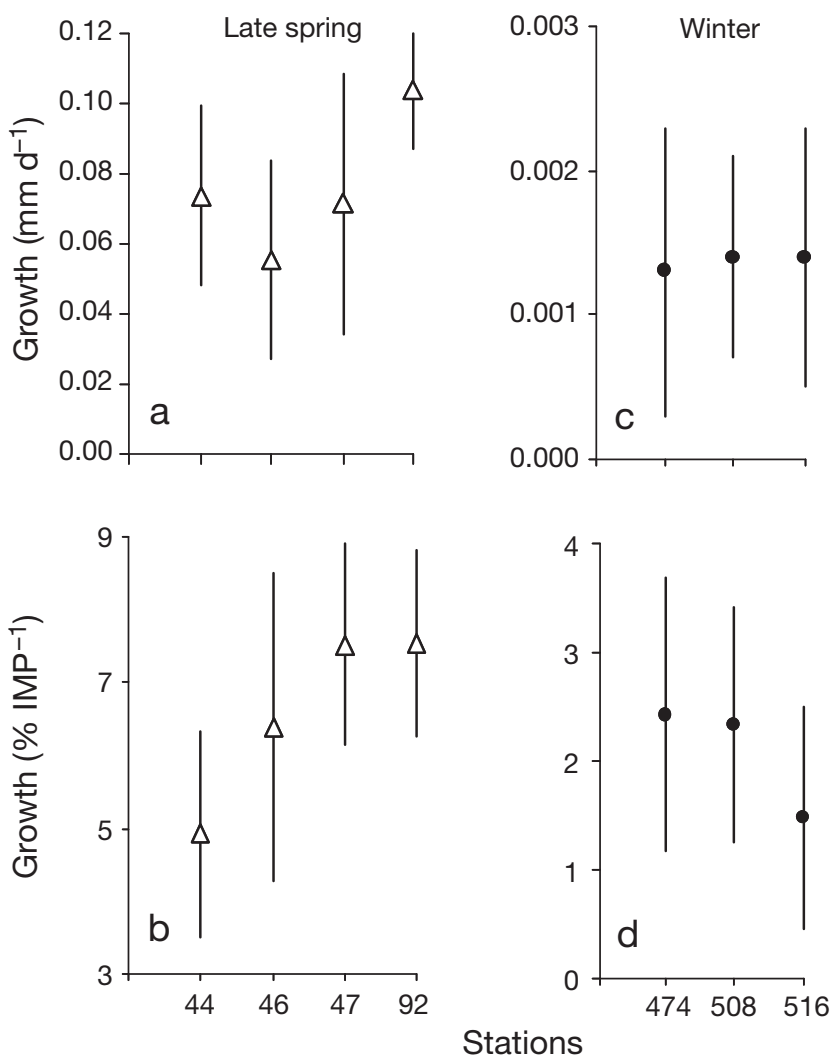

Fig. 7. Euphausia superba. $(\mathrm{a}, \mathrm{b})$ Late spring and $(\mathrm{c}, \mathrm{d})$ winter $(\mathrm{a}, \mathrm{c})$ growth rate and $(\mathrm{b}, \mathrm{d})$ growth increment $(\mathrm{GI})$ in \% per intermoult period (IMP), (mean $\pm \mathrm{SE}$ ). Note different scales for late spring and winter

during the dark season. Shrinkage of krill in the field might be a result of prolonged starvation and consequently severe physical conditions.

Compared with results from previous growth rate studies using the IGR method, the growth rates of krill from the Lazarev Sea in December are moderate ( $0.076 \mathrm{~mm} \mathrm{~d}^{-1}$ on average), in contrast to those measured overall in the Scotia Sea in January and February, where growth rates reached $0.32 \mathrm{~mm} \mathrm{~d}^{-1}$, with mean values of $0.1 \mathrm{~mm} \mathrm{~d}^{-1}$ (Atkinson et al. 2006). On the other hand, growth rates similar to those in the Lazarev Sea in late spring were found around South Georgia (Arnold et al. 2004) and off east Antarctica (Nicol et al. 2000) during summer. In winter in the Lazarev Sea, the IMP was nearly twice as long as in late spring, which is consistent with previous studies (Quetin \& Ross 1991, Buchholz et al. 1989). However, the IMP in late spring (December) was much longer than that reported from studies made in January and February (e.g. Buchholz et al. 1989, Arnold 2004). As outlined in Buchholz (1991, 2003), growth and IMP are functions of energy intake, temperature, length and maturity. The use of mainly subadult krill of similar length in our growth experiments during both seasons ensured that growth variability due to length and sexual maturation, as compared to other studies, can be neglected (Buchholz 2003). The same is true for temperature, which was very similar in both seasons (late spring: $-1.5^{\circ} \mathrm{C}$, winter: $-1.8^{\circ} \mathrm{C}$ ). In the Lazarev Sea, phytoplankton blooms just started to develop in December, so that lipid storage of krill was still low after the winter depletion. These circumstances might explain the moderate growth rates and long IMPs in the Lazarev Sea in December compared to previous growth studies performed in January and February (see above).

\section{Influence of the Antarctic light regime on physiological functions}

It is still under debate whether the low food supply is the only reason for the low metabolic rate in krill during winter or whether there is a more fundamental seasonal transition in the krill's physiology induced by environmental cues (Torres et al. 1994b). First indications for such a cue were reported by Kawaguchi et al. (1986). The authors reported a decline of physiological functions (feeding and metabolic activity) in krill from April and May to August and September and a slow but steady increase thereafter. This correlated exclusively with solar radiation and not food availability. Most recently, more clarity was brought to this topic from controlled experiments in the laboratory. Feeding, metabolic activity (Teschke et al. 2007) and gene expression (Seear et al. 2009) of krill were affected by the Antarctic light regime. Simulated summer conditions (24 h light) caused high feeding and metabolic rates as well as increased expression of genes involved in functions such as metabolism, motor activity, protein binding and various other cellular activities. In contrast, simulated winter conditions (no light) led to the opposite results. In the Lazarev Sea, krill showed significant differences in feeding activity between seasons. In contrast to late spring, krill were unable to respond to high food concentrations in autumn and winter, despite exposure to abundant food for up to 2 wk (Fig. 4). Together, laboratory and field findings indicate that reduced feeding and metabolic activity of krill during Antarctic winter are not caused directly by the scarcity of food at this time of the year, but represent an inherent adaptational overwintering mechanism influenced by the Antarctic light regime. However, the effects of latitudinal differences on metabolic and feeding activity of krill during winter due to differences in daylight duration are unknown. It also remains unclear whether the observed effects on physiological functions of krill from the field are the result of differences in photoperiods or light intensity. During laboratory experiments carried out by Teschke et al. 


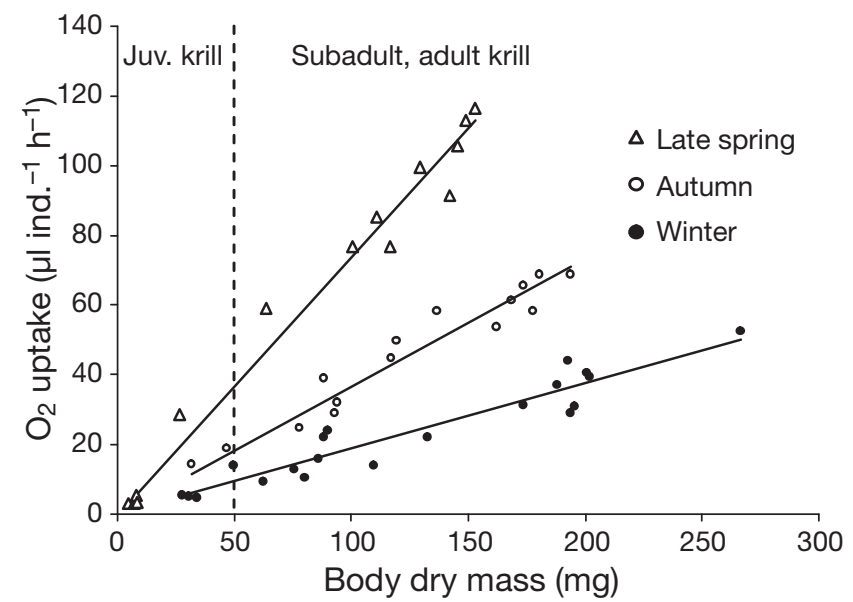

Fig. 8. Euphausia superba. Relationship of body dry mass and oxygen uptake rates of individual krill in different seasons. The linear regressions are shown in Table 7. Juvenile, subadult and adult krill were defined after Siegel (1987)

(2007), the light regimes were adjusted to different photoperiods and light intensities, in order to simulate the seasonal Antarctic light regime most accurately. These open questions warrant future research. It appears that the influence of the light regime may vary during krill ontogenesis. Adults showed significant differences in metabolic rates between seasons (Fig. 8, Table 7), whereas the seasonal metabolic differences are less pronounced in juvenile krill (Fig. 8). Recent investigations have demonstrated that metabolic activity in larval krill depends exclusively on food supply and not on light (Meyer et al. 2009). It is also unknown whether the shift takes place abruptly with the final larval moult or whether there is a subtle transition during juvenile stage.

\section{Energy provision during winter}

Although physiological functions are reduced to a minimum, energy must be provided in order for the organism to function, albeit at low rates, for several months during the absence of autotrophic food in the water column. There seem to be 2 adaptations to accomplish this: (1) accumulation of large lipid reserves during summer until the onset of winter for winter consumption and (2) an omnivorous feeding activity at low rates during winter.

\section{Lipid and protein utilisation}

It is now well known that Antarctic krill accumulate large reserves of body lipids during the course of summer when availability of phytoplankton is high, and consume these reserves during the winter season (Hagen et al. 2001). Our study confirms this for the Lazarev Sea. The lipid content showed strong seasonality (Table 3), with highest lipid levels in April (32\% $\left.\mathrm{DM}^{-1}\right)$ and lowest values in December $\left(5 \% \mathrm{DM}^{-1}\right)$. Furthermore, the metabolic enzyme HOAD, an indicator for lipid breakdown (turnover), showed significantly higher activities in winter krill than in those sampled in late spring and autumn (Table 6). In addition, the low $\mathrm{O}: \mathrm{N}$ ratio (15) of krill in autumn (April) indicated that they had not yet resorted to burning these reserves (Atkinson et al. 2002). On the other hand, the high O:N ratio (66) in winter krill (July and August) demonstrated full usage of lipid reserves (Ikeda et al. 2000). Krill from the eastern and western Weddell Sea and the Lazarev Sea showed average lipid depletion from their initial values in April and May (mid to late autumn) to October and November (mid to late spring) by $70 \%$ (Hagen et al. 2001). In the WAP and the Southern Scotia-Northern Weddell Sea region, lipid levels in krill declined 40 to $50 \%$ from early to mid autumn (March and April) until late winter (August and September, Quetin \& Ross 1991, Torres et al. 1994b). It appears that the rate of lipid depletion in krill during winter is approximately $10 \% \mathrm{mo}^{-1}$ of their initial lipid levels at the onset of winter.

In our study, the mid autumn and late spring season was not researched in consecutive seasons, so we are cautious in interpreting the lipid levels of krill in April 2004 and December 2005 as a seasonal sequence. In the Lazarev Sea, the remaining lipid content of $5 \%$ $\mathrm{DM}^{-1}$ in December 2005 is very low and on the border of what is deemed essential for the functioning of biomembranes and hence survival (Hagen et al. 2001). Such low reserves in krill were documented previously in late October to mid November (Hagen et al. 2001). The accumulation of energy reserves during the feeding season until the onset of winter depends on the quantity and quality of phytoplankton during the preceding summer and autumn (Hagen et al. 2001). In the Lazarev Sea, food supply in terms of chl $a$, varied considerably from year to year. The mean March chl a concentrations were $0.4,0.2$, and $0.8 \mathrm{mg} \mathrm{m}^{-3}$ in 2004 , 2005 and 2006, respectively (Fig. 9). The low body lipid content of krill in December 2005 might therefore be the result of low initial lipid storage in krill at the onset of winter in April and May 2005. It is most likely that this lipid level (April and May 2005) was lower than that measured in April 2004 due to the lack of favourable feeding conditions during summer 2005 (Fig. 9b). Low lipid reserves at the beginning of winter and any delay in the availability of adequate food in spring would affect the onset and success of the spawning season, which then sets up the reproductive success of the entire year class (e.g. Siegel \& Loeb 


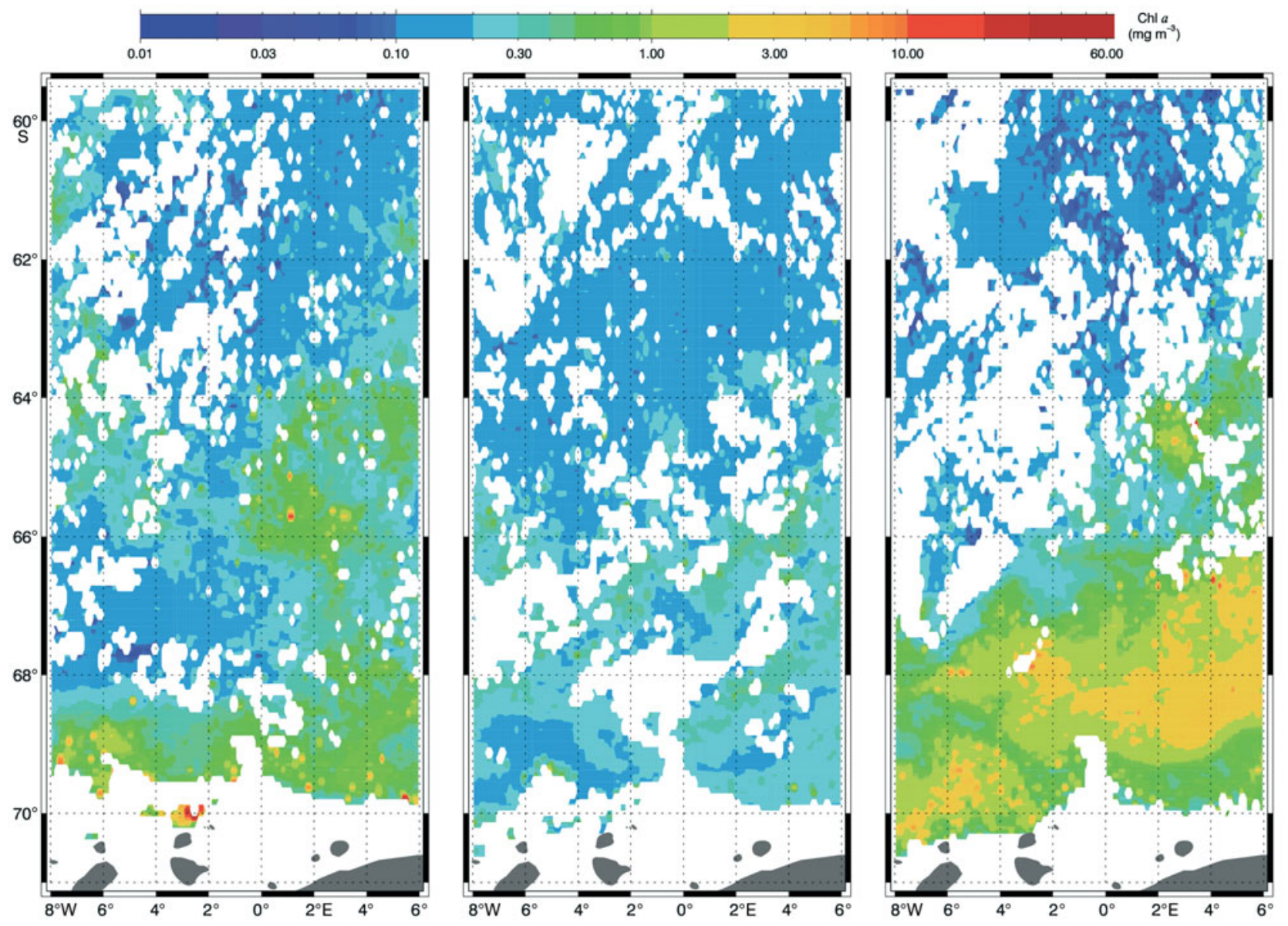

Fig. 9. Monthly mean SeaWiFS chlorophyll a $\left(\mathrm{mg} \mathrm{m}^{-3}\right)$ in March of (a) 2004, (b) 2005, and (c) 2006. White: no data

1995). This highlights the importance of favourable feeding conditions during summer to accumulate sufficient energy reserves for a successful overwintering period of krill.

Compared with lipids, proteins play a minor role as an energy reserve in overwintering krill. Krill from the Southern Scotia-Northern Weddell Sea region depleted protein levels from March to August by $16 \%$ (Torres et al. 1994b). Such utilisation is minor (ca. $3 \% \mathrm{mo}^{-1}$ ) compared to the lipid depletion in krill during winter. In the Lazarev Sea, similarly sized krill had a mean individual protein content of $30 \mathrm{mg} \mathrm{DM}^{-1}$ in winter (July 2006) and $24 \mathrm{mg} \mathrm{DM}^{-1}$ in late spring (December 2005), suggesting a negligible utilisation of body protein during winter. The moderate use of body protein in krill during winter is also confirmed by the relationship between $\mathrm{N}$ and protein. In our multi-seasonal study, this relationship did not differ significantly and a slope of 4.8 (Table 4 ) indicates that most of the $\mathrm{N}$ is bound in the muscle protein fraction (Anger 2001). A significantly increased utilisation of body protein and/or digestion of heterotrophic diet would result in an increase of $\mathrm{N}$ and a decrease of muscle protein con- tent, measurable as a shallower slope of the N:protein relationship and increasing excretion rates. This was demonstrated recently for larval krill (Meyer et al. 2009). Neither was found in adult krill, suggesting that the use of body protein and/or a heterotrophic diet during winter was minor compared with the use of stored lipids during the study period in the Lazarev Sea.

\section{Food sources during winter}

Most authors addressing the overwintering of krill mention the possibility of switching to alternative food sources other than phytoplankton in the water column, such as zooplankton, phytodetritus in shallow regions and ice algae. When comparing results from various feeding studies during winter (summarised in Table 10), however, it becomes apparent that krill display more of an opportunistic feeding behaviour rather than a preference for a specific food source during winter. Several studies have demonstrated that colouration of the DG (Kawaguchi et al. 1999, Nicol et al. 2004) and the stomach (Kawaguchi et al. 1986) is related to the ingested 
Table 10. Euphausia superba. Studies of feeding during the Antarctic winter. The stomach and gut contents are listed in order of their abundance

\begin{tabular}{|c|c|c|}
\hline Measurement & Results & Source \\
\hline \multicolumn{3}{|l|}{ Field studies } \\
\hline \multirow[t]{6}{*}{ Stomach and gut content } & Phytoplankton: diatoms, dinoflagellates & Lancraft et al. (1991), \\
\hline & Protozoan: tintinnids & Hopkins et al. (1993) \\
\hline & Metazoans: Oithona, other copepods & \\
\hline & Euphausiid debris: moults & \\
\hline & Phytoplankton: diatoms, dinoflagellates, silicoflagellates & Nishino \& Kawamura (1994) \\
\hline & $\begin{array}{l}\text { Protozoa: foraminifera, tintinnids, radiolarians, naked ciliates } \\
\text { Metazoa: copepods }\end{array}$ & \\
\hline Stomach colour and gut content & Light green & Daly \& Macaulay (1991) \\
\hline \multirow[t]{2}{*}{ Colour of digestive gland } & Yellowish brown or ochre & Kawaguchi et al. (1986) \\
\hline & Transparent, milky white or pale yellow & Present study \\
\hline \multicolumn{3}{|l|}{ Laboratory studies } \\
\hline Feeding rates & High feeding activity on Oithona spp., Oncaea spp. & Huntley et al. (1994) \\
\hline
\end{tabular}

food source. Phytoplankton diet is indicated by a black-green, yellow and/or greenish DG (Kawaguchi et al. 1999), phytodetritus by a brownish ochre stomach and gut (Kawaguchi et al. 1986), and a milky-white DG is an indicator of a zooplankton diet (Atkinson et al. 2002). In the Lazarev Sea, the small size of the DG in winter compared with late spring (Figs. 5 \& 6) and its colouration ranging from colourless to milky white (Fig. 6c) or pale yellow (Fig. 6d) suggested that krill had either not been feeding or had ingested a heterotrophic and autotrophic diet at low rates.

The majority of krill feeding studies performed in winter found low feeding activity (Table 9). However, an investigation by Huntley et al. (1994) reported a high feeding activity of krill on small zooplankton organisms (Oithona spp, Oncaea spp.). Another study implies in its title that a winter study was performed and a high feeding activity of krill on ice algae was observed (Marschall 1988). However, this observation was made between the middle and end of October (Hempel 1987). In the light of the preceding discussion, at this time of the year, the high feeding activity of krill on ice algae is not surprising. Feeding activity, growth and metabolic rate start increasing at the onset of spring despite low food availability (Mackintosh 1972, Stepnik 1982, Morris \& Priddle 1984, Kawaguchi et al. 1986). During the middle to end of October, it is most likely that the krill had already returned to their active physiological mode due to changes in the Antarctic light regime.

\section{A compromise strategy used by krill for overwintering}

Torres et al. (1994b) were the first to propose a compromise strategy for overwintering krill. Our study has demonstrated that the Antarctic light regime (and not food supply) seems to be the single most important ecological cue for commencement of physiological adaptation to winter. During this adaptation, metabolic activity is reduced to a minimum and reflects low feeding and low growth (or even shrinkage). Overwintering success, however, depends on the sufficient accumulation of energy reserves (mainly lipids) during the preceding productive season. However, the flexible (omnivorous) feeding activity, at low rates, during winter contributes to a valuable energy input. Therefore, during studies investigating seasonal feeding activity of krill based on stomach content analyses, a rough estimate of the energy content of the ingested food should be made rather than just an inventory of the food items.

Acknowledgements. We thank the captain and crew of RV 'Polarstern' for their professional support on all cruises. We are grateful to the National Aeronautics and Space Administration (NASA) and the National Oceanic and Atmospheric Administration (NOAA) for the use of satellite-derived chl a and sea ice data. We also thank L. Friedrich for preparing the pictures to demonstrate the size and colouration of the digestive gland of freshly caught krill in late spring and winter. This work was supported by funding from the German Ministry of Education and Research (BMBF) through project 03F0400A, Subproject 4 of the Lazarev Sea Krill Study (LAKRIS) Project, the International Bureau of the BMBF through project SUA 05/008, and the Natural Environment Research Council (United Kingdom, AFI 5/09). The LAKRIS Project is the German contribution to the Southern OceanGlobal Ocean Ecosystem Dynamics (SO-GLOBEC) program.

\section{LITERATURE CITED}

Anger K (2001) Chemical composition. In: Vonk R (ed) The biology of decapod crustacean larvae. Crustacean Issues 14, A. Balkema Publishers, Rotterdam, p 183-211

Arnold K, Shreeve RS, Atkinson A, Clarke A (2004) Growth rates of Antarctic krill, Euphausia superba: comparison of the instantaneous growth rate method with nitrogen and phosphorus stoichiometry. Limnol Oceanogr 49:2152-2161 
Atkinson A, Snÿder R (1997) Krill-copepod interactions at South Georgia, Antarctica. I. Omnivory by Euphausia superba. Mar Ecol Prog Ser 160:63-76

Atkinson A, Meyer B, Stübing D, Hagen W, Bathmann UV (2002) Feeding and energy budgets of Antarctic krill Euphausia superba at the onset of winter. II. Juveniles and adults. Limnol Oceanogr 47:953-966

Atkinson A, Siegel V, Pakhomov EA, Rothery P (2004) Longterm decline in krill stock and increase in salps within the Southern Ocean. Nature 432:100-103

Atkinson A, Shreeve RS, Hirst AG, Rothery P, Tarling GA, Pond DW, Korb RE, Murphy EJ, Watkins JL (2006) Natural growth rates in Antarctic krill (Euphausia superba). II. Predictive models based on food, temperature, body length, sex, and maturity stage. Limnol Oceanogr 51: 973-987

Atkinson A, Siegel V, Pakhomov EA, Rothery P and others (2008) Oceanic circumpolar habitats of Antarctic krill. Mar Ecol Prog Ser 362:1-23

Auerswald L, Gäde G (1999) The fate of proline in the African fruit beetle Pachnoda sinuata. Insect Biochem Mol Biol 29:687-700

Auerswald L, Pape C, Stübing D, Lopata AL, Meyer B (2009) Effect of short-term starvation of adult Antarctic krill, Euphausia superba, at the onset of summer. J Exp Mar Biol Ecol 381:47-56

Båmstedt U, Gifford DJ, Irigoien X, Stkinson A, Roman M (2000) Feeding. In: Harris RP, Wiebe PH, Lenz J, Skjoldal HR, Huntley $M$ (eds) ICES zooplankton methodology manual. Academic Press, London, p 297-399

Bradford MM (1976) A rapid and sensitive method for the quantitation of microgram quantities of protein utilizing the principle of protein-dye binding. Anal Biochem 72: 248-254

Buchholz F (1991) Moult cycle and growth of Antarctic krill Euphausia superba in the laboratory. Mar Ecol Prog Ser 69:217-229

Buchholz F (2003) Experiments on the physiology of southern and northern krill, Euphausia superba and Meganyctiphanes norvegica, with emphasis on moult and growtha review. Mar Freshwat Behav Physiol 36:229-247

Buchholz F, Morris DJ, Watkins JL (1989) Analyses of field moult data: prediction of intermoult period and assessment of seasonal growth in Antarctic krill, Euphausia superba Dana. Antarct Sci 1:301-306

Daly KL (2004) Overwintering growth and development of larval Euphausia superba an interannual comparison under varying environmental conditions west of the Antarctic Peninsula. Deep-Sea Res II 51:2139-2168

Daly KL, Macaulay MC (1991) Influence of physical and biological mesoscale dynamics on the seasonal distribution and behaviour of Euphausia superba in the Antarctic marginal ice zone. Mar Ecol Prog Ser 79:37-66

Ettershank G (1983) Age structure and cyclical annual size change in the Antarctic krill, Euphausia superba Dana. Polar Biol 2:189-193

> Garrison DL, Gibson A, Coale SL, Gowing MM, Okolodkov YB, Fritsen CH, Jeffries MO (2005) Sea-ice microbial communities in the Ross Sea: autumn and summer biota. Mar Ecol Prog Ser 300:39-52

Hagen W (2000) Lipids. In: Harris RP, Wiebe PH, Lenz J, Skjoldal HR, Huntley M (eds) ICES zooplankton methodology manual. Academic Press, London, p 113-119

> Hagen W, Kattner G, Terbrüggen A, Van Vleet ES (2001) Lipid metabolism of the Antarctic krill Euphausia superba and its ecological implications. Mar Biol 139:95-104

Hempel G (1987) Itinerary ANT V/3 (Cape Town-Cape
Town). In: Schnack-Schiel S (ed) The winter expedition of RV Polarstern to the Antarctic (ANT V/1-3). Ber Polarforsch 39:127-141.

> Hirche HJ (1983) Excretion and respiration of the Antarctic krill Euphausia superba. Polar Biol 1:205-209

Hofmann EE, Wiebe PH, Costa DP, Torres JJ (2004) An overview of the Southern Ocean GLOBEC Ecosystems Dynamics program. Deep-Sea Res II 51:1921-1924

> Hopkins TL, Lancraft TM, Torres JJ, Donelly J (1993) Community structure and trophic ecology of zooplankton in the Scotia Sea marginal ice zone in winter (1988). Deep-Sea Res I 40:81-105

> Huntley ME, Nordhausen W, Lopez MDG (1994) Elemental composition, metabolic activity and growth of Antarctic krill Euphausia superba during winter. Mar Ecol Prog Ser $107: 23-40$

Ikeda T (1985) Life history of Antarctic krill Euphausia superba: A new look from an experimental approach. Bull Mar Sci 37:599-608

> Ikeda T, Bruce B (1986) Metabolic activity and elemental composition of krill and other zooplankton from Prydz Bay, Antarctica, during early summer (November-December). Mar Biol 92:545-555

Ikeda T, Dixon P (1982) Body shrinkage as a possible overwintering mechanism of the Antarctic krill, Euphausia superba Dana. J Exp Mar Biol Ecol 62:143-151

Ikeda T, Mitchell AW (1982) Oxygen uptake, ammonia excretion and phosphate excretion by krill and other Antarctic zooplankton in relation to their body size and chemical composition. Mar Biol 71:283-298

Ikeda T, Thomas PG (1987) Longevity of the Antarctic krill (Euphausia superba Dana) based on a laboratory experiment. Proc NIPR Symp Polar Biol 1:56-62

Ikeda T, Torres JJ, Hernandez-Leon S, Geiger SP (2000) Metabolism. In: Harris RP, Wiebe PH, Lenz J, Skjoldal HR, Huntley M (eds) ICES zooplankton methodology manual. Academic Press, London, p 455-532

Johnson MA, Macaulay MC, Biggs DC (1984) Respiration and excretion within a mass aggregation of Euphausia superba: Implications for krill distribution. J Crustac Biol 4:174-184

> Kang SH, Kang JS, Lee S, Chung KH, Kim D, Park MD (2001) Antarctic phytoplankton assemblages in the marginal ice zone of the northwestern Weddell Sea. J Plankton Res 23: $333-352$

Kawaguchi K, Ishikawa S, Matsuda O (1986) The overwintering strategy of Antarctic krill (Euphausia superba Dana) under the coastal fast ice off the Ongul Islands in LützowHolm Bay, Antarctica. Mem Natl Inst Polar Res 44(Spec Issue):67-85

Kawaguchi S, Ishii T, Naganobu M (1999) Green krill, the indicator of micro- and nano-size phytoplankton availability to krill. Polar Biol 22:133-136

Kils U (1978) Performance of Antarctic krill Euphausia superba, at different levels of oxygen saturation. Meeresforschung/Rep Mar Res 27:35-47

> Lancraft TM, Hopkins TL, Torres JJ, Donelly J (1991) Oceanic micronektonic/macrozooplanktonic community structure and feeding in ice covered Antarctic waters during winter (AMERIEZ 1988). Polar Biol 11:157-167

Lizotte MP (2003) The microbiology of sea ice In: Thomas DN, Dieckmann GS (eds) Sea ice. Blackwell Science, p 184-210

Loeb V, Siegel V, Holm-Hansen O, Hewitt R, Fraser W, Trivelpiece W, Trivelpiece S (1997) Effects of sea-ice extent and krill or salp dominance on the Antarctic food web. Nature 387:897-900

Lowry OH., Rosebrough NJ, Farr AL, Randall RJ (1951) Protein measurement with the Folin phenol reagent. J Biol 
Chem 193:265-275

Mackintosh NA (1972) Life cycle of Antarctic krill in relation to ice and water conditions. Disc Rep 36:1-94

Makarov RR, Sysoyeva MV (1985) Biology and distribution of Euphausia superba in the Lazarev Sea and adjacent waters. In: Legkaya i pishevaya promyshlennost. Antarktichestkiy Kril Osobennosti Raspredeleniya I Sreda, Moscow, p 110-116

Marr JWS (1962) The natural history and geography of the Antarctic krill (Euphausia superba Dana). Disc Rep 32: 33-464

Marschall HP (1988) The overwintering strategy of Antarctic krill under the pack-ice of the Weddell Sea. Polar Biol 9:129-135

Meyer B, Atkinson A, Stübing D, Oettl B, Hagen W, Bathmann UV (2002a) Feeding and energy budgets of Antarctic krill Euphausia superba at the onset of winter. I. Furcilia III larvae. Limnol Oceanogr 47:943-952

Meyer B, Saborowski R, Atkinson A, Buchholz F, Bathmann U (2002b) Seasonal differences in citrate synthase and digestive activity in larval and postlarval Antarctic krill, Euphausia superba. Mar Biol 141:855-862

> Meyer B, Atkinson A, Blume B, Bathmann UV (2003) Feeding and energy budgets of larval Antarctic krill Euphausia superba in summer. Mar Ecol Prog Ser 257:167-178

Meyer B, Fuentes V, Guerra C, Schmidt K and others (2009) Physiology, growth and development of larval krill Euphausia superba in autumn and winter in the Lazarev Sea, Antarctica. Limnol Oceanogr 54:1595-1614

Morris DJ, Priddle J (1984) Observations on the feeding and moulting of the Antarctic krill, Euphausia superba Dana, in winter. Br Antarct Surv Bull 65:57-63

Morris DG, Ward P, Clarke A (1983) Some aspects of feeding in the Antarctic krill, Euphausia superba. Polar Biol 2:21-26

Nicol S, Stolp M, Cochran T, Geijsel T, Marshall J (1992) Growth and shrinkage of Antarctic krill Euphausia superba from the Indian Ocean sector of the Southern Ocean during summer. Mar Ecol Prog Ser 89:175-181

Nicol S, Kitchener J, King R, Hosie G, de la Mare WK (2000) Population structure and condition of Antarctic krill (Euphausia superba) off east Antarctica $\left(80-150^{\circ} \mathrm{E}\right)$ during the Austral summer of 1995/1996. Deep Sea Res II 47: $2489-2517$

Nicol S, Virtue King R, Davenport SR, McGaffin AF, Nichols P (2004) Condition of Euphausia crystallorophias off East Antarctica in winter in comparison to other seasons. DeepSea Res II 51:2215-2224

Nishino Y, Kawamura A (1994) Winter gut contents of Antarc-

Editorial responsibility: Hans Heinrich Janssen, Oldendorf/Luhe, Germany tic krill (Euphausia superba Dana) collected in the South Georgia area. Proc NIPR Symp Polar Biol 7:82-90

Palmisano AC, Sulivan CW (1983) Sea ice microbial communities (SIMCO). Polar Biol 2:171-177

Quetin LB, Ross RM (1991) Behavioural and physiological characteristics of the Antarctic krill, Euphausia superba. Am Zool 31:49-63

Rakusa-Suszczewski S, Opalinski KW (1978) Oxygen consumption in Euphausia superba. Pol Arch Hydrobiol 25:633-641

Schmidt K, Atkinson A, Stübing D, McClelland JW, Montoya JP, Voss M (2003) Trophic relationships among Southern Ocean copepods and krill. Some uses and limitations of a stable isotope approach. Limnol Oceanogr 48:277-289

Seear P, Geraint AT, Teschke M, Meyer B and others (2009) Effects of simulated light regimes on gene expression in Antarctic krill (Euphausia superba Dana). J Exp Mar Biol Ecol 381:57-64

Siegel V (1987) Age and growth of Antarctic Euphausiaceae (Crustacea) under natural conditions. Mar Biol 96:483-495

Siegel V, Loeb V (1995) Recruitment of Antarctic krill Euphausia superba and possible causes for its variability. Mar Ecol Prog Ser 123:45-56

Solorzano L (1969) Determination of ammonia in natural waters by the phenolhypochlorite method. Limnol Oceanogr 14: 799-801

Stepnik R (1982) All-year population studies of Euphausiaceae (Crustacea) in the Admiralty Bay (King George Island, South Shetland Island, Antarctica). Pol Polar Res 3:49-68

Stitt M (1984) Citrate synthase (condensing enzyme). In: Bergmeyer HU (ed) Methods of enzymatic analysis, Vol IV. Chemie, Weinheim, p 353-358

Stübing D, Hagen W (2003) Fatty acid biomarker ratios - suitable trophic indicators in Anatarctic euphausiids. Polar Biol 26:774-782

Teschke M, Kawaguchi S, Meyer B (2007) Simulated light regimes affect feeding and metabolism of Antarctic krill, Euphausia superba. Limnol Oceanogr 52:1046-1054

> Torres JJ, Aarset AV, Donnelly J, Hopkins TL, Lancraft TM, Ainley DG (1994a) Metabolism of Antarctic micronektonic Crustacea as a function of depth of occurrence and season. Mar Ecol Prog Ser 113:207-219

> Torres JJ, Donnelly J, Hopkins TL, Lancraft TM, Aarset AV, Ainley DG (1994b) Proximate composition and overwintering strategies of Antarctic micronektonic Crustacea. Mar Ecol Prog Ser 113:221-232

Zar JH (1999) Biostatistical analysis. Prentice-Hall, Englewood Cliffs, New Jersey

Submitted: June 8, 2009; Accepted: October 13, 2009

Proofs received from author(s): December 15, 2009 